\title{
ELECTRICALLY SWITCHED CESIUM ION EXCHANGE
}

\section{FY 1996 Annual Report}

Michael A. Lilga

Rick J. Orth

Johanes P. H. Sukamto

Daniel T. Schwartz

Scott M. Haight

University of Washington

David Genders

Electrosynthesis Company, Inc.

December 1996

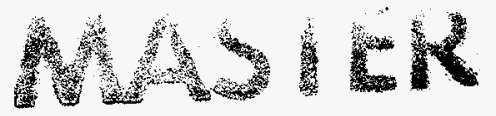

Prepared for

the Office of Science and Technology

U.S. Department of Energy's Office of Environmental Management

Efficient Separations and Processing Crosscutting Program

under Contract DE-AC06-76RLO 1830

Pacific Northwest National Laboratory

Richland, Washington 99352 



\section{Summary}

An electrochemical method for metal ion separations, called Electrically Switched Ion Exchange (ESIX), is described in this report. In this method, direct oxidation and reduction of an electroactive film attached to an electrode surface is used to load and unload the film with alkali metal cations. The electroactive films under investigation are nickel hexacyanoferrates, which are deposited on the surface by applying an anodic potential to a nickel electrode in a solution containing the ferricyanide anion. Reported film preparation procedures have been modified to produce films with improved capacity and stability. Electrochemical behavior of the derivatized electrodes has been investigated with use of cyclic voltammetry and chronocoulometry. The films show selectivity for cesium in concentrated sodium solutions. Raman spectroscopy has been used to directly monitor changes in oxidation state of the film and imaging experiments have demonstrated that the redox reactions are spatially homogeneous across the film. Requirements for a bench scale unit have been identified.

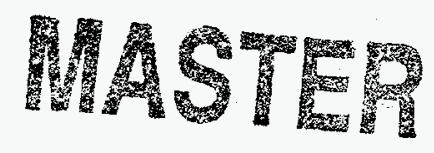





\section{DISCLAIMER}

Portions of this document may be illegible in electronic image products. Images are produced from the best available original document. 


\section{Acknowledgments}

This work was funded by the Office of Science and Technology within the Department of

Energy's Office of Environmental Management and under the Efficient Separations and Processing Crosscutting Program. 



\section{Acronyms and Abbreviations}

A electrode surface area

A amps

C charge

C Coulombs

$C_{0}^{*} \quad$ concentration of electroactive film

$D_{a p p} \quad$ apparent diffusion coefficient

DOE U.S. Department of Energy

EIX electrochemical ion exchange

ESIX electrically switched ion exchange

F $\quad$ Faraday constant

HLW high-level waste

IX ion exchange

LLW low-level waste

NRC U.S. Nuclear Regulatory Commission

SCE saturated calomel electrode

$t \quad$ time

TFE poly(tetrafluoroethylene)

V volts 



\section{Contents}

Summary $\ldots \ldots \ldots \ldots \ldots \ldots \ldots \ldots \ldots \ldots \ldots \ldots \ldots \ldots \ldots \ldots$

Acknowledgments $\ldots \ldots \ldots \ldots \ldots \ldots \ldots \ldots \ldots \ldots \ldots \ldots \ldots \ldots \ldots$

Acronyms and Abbreviations $\ldots \ldots \ldots \ldots \ldots \ldots \ldots \ldots \ldots \ldots \ldots \ldots$

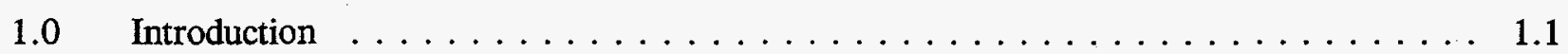

2.0 Work Accomplished $\ldots \ldots \ldots \ldots \ldots \ldots \ldots \ldots \ldots \ldots \ldots \ldots$

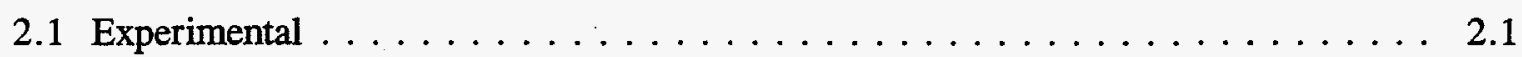

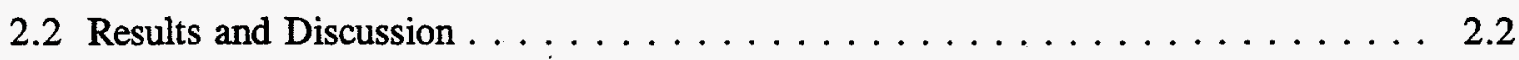

2.2.1 Comparison of Film Preparation Methods $\ldots \ldots \ldots \ldots \ldots \ldots$

2.2.2 Cesium Uptake/Elution $\ldots \ldots \ldots \ldots \ldots \ldots \ldots \ldots \ldots \ldots$

2.2.3 Estimation of Rates of Ion Loading and Unloading $\ldots \ldots \ldots \ldots \ldots$

2.2.4 Film Characterization Using Raman Spectroscopy . . . . . . . . . . 2.12

2.2.5 Scale-up Considerations $\ldots \ldots \ldots \ldots \ldots \ldots \ldots \ldots \ldots \ldots \ldots \ldots$

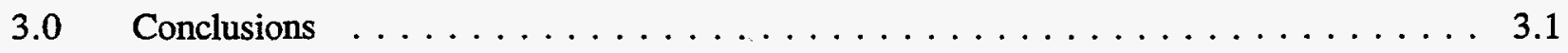

$4.0 \quad$ References $\ldots \ldots \ldots \ldots \ldots \ldots \ldots \ldots \ldots \ldots \ldots \ldots \ldots$

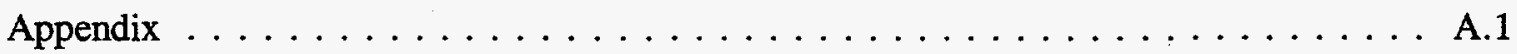




\section{Figures}

1 The ESIX concept for metal ion loading and unloading $\ldots \ldots \ldots \ldots \ldots \ldots$

2 Cyclic voltammetry of a bare nickel electrode in $1 M \mathrm{NaNO}_{3} \ldots \ldots \ldots \ldots$

3 Cyclic voltammetry in $1 M \mathrm{NaNO}_{3}$ of hexacyanoferrate films prepared by three different

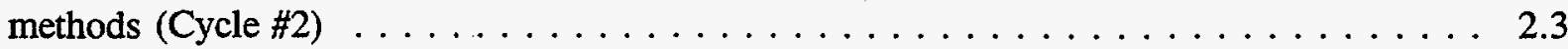

4 Charge passed as determined by integration of a single potential cycle (Cycle \#2) for

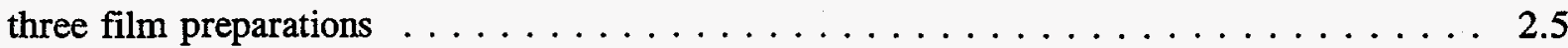

5 Repeated potential cycling of PNNL-1 in $1 M^{2} \mathrm{NaNO}_{3} \ldots \ldots \ldots \ldots$

6 Maximum charge passed as a function of cycle number for three different film preparations (cyclic voltammetry in $1 M \mathrm{NaNO}_{3}$ ) $\ldots \ldots \ldots \ldots \ldots \ldots$

7 Normalized maximum charge as a function of cycle number for three different film preparations (cyclic voltammetry in $\left.1 \mathrm{MNaNO}_{3}\right) \ldots \ldots \ldots \ldots \ldots \ldots$

8 Cyclic voltammetry for a film in the cesium form and after two and 25 potential cycles

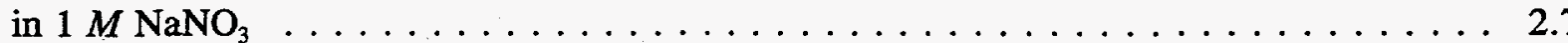

9 Cyclic voltammetry of a film in the sodium form and after two potential cycles in

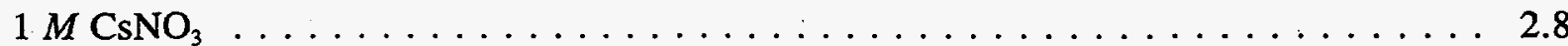

10 Loading of a film in the sodium form in $1 M \mathrm{NaNO}_{3}$ and the same film in the cesium form in $1 \mathrm{M} \mathrm{CsNO}_{3}$

11 Normalized charge as a function of time for three different film preparations (from cyclic voltammetry in $1 \mathrm{M} \mathrm{NaNO}_{3}$ )

12 Potential step loading $(0.25 \mathrm{~V})$ and unloading $(0.50 \mathrm{~V})$ of a film prepared by the literature method

13 Cottrell plot for unloading sodium from a film prepared by the literature method

14 Raman spectra of hexacyanoferrate films on a nickel wire as a function of applied potential

15 Imaging Raman spectra of a literature film on a nickel wire showing spatially homogeneous redox reactions 


\subsection{Introduction}

A variety of waste types containing radioactive ${ }^{137} \mathrm{Cs}$ are found throughout the U.S. Department of Energy (DOE) complex. These waste types include reactor cooling basins (Hanford, Savannah River), underground storage tanks containing high-level radioactive waste (Savannah River, Idaho, Oak Ridge, and Hanford), and occasionally groundwater (Idaho). Safety and regulatory requirements and economic considerations necessitate the removal of radiocesium before these wastes can be permanently disposed of as low-level waste (LLW) (Gephart and Lundgren 1995; PNNL 1996).

Underground storage tanks contain high-level mixed wastes in forms of sludge, salt cake, and alkaline supernatant liquors. The current treatment scenario for this waste includes vitrification of the high-level waste (HLW) for storage in a geologic repository and immobilization of the LLW for near-surface disposal. Because of the high cost of HLW disposal, separation and concentration of the radionuclides is needed to minimize the volume of HLW so that most of the waste may be disposed of less expensively as LLW. Although the disposal requirements for LLW at Hanford have not been set, the Nuclear Regulatory Commission (NRC) Class A waste form can contain no more than $1 \mathrm{Ci} / \mathrm{m}^{3}$. Using the volume reduction achievable by the current vitrification technology, the concentration of ${ }^{137} \mathrm{Cs}$ in the feed to the LLW vitrifier may be at most $0.42 \mathrm{Ci} / \mathrm{m}^{3}$ (Kurath et al. 1994). Accounting for the non-radioactive cesium in the waste (mass ${ }^{137} \mathrm{Cs} /$ total $\mathrm{Cs}$ mass $=0.38$ ), the highest allowable total cesium concentration in the feed would be about $9.3 \times 10^{-8} \mathrm{M}$. The concentration of cesium in tank waste depends on which process generated the waste, but the highest is on the order of $5.1 \times 10^{-4} \mathrm{M}$, requiring the separation process to have a decontamination factor of at least 5500 (Kurath et al. 1994). The separation must also be selective for cesium in the presence of sodium concentrations that can be $10^{5}$ times higher.

Spent nuclear fuel storage basins and groundwater contain radioactive cesium and other radionuclides at much lower concentrations. For example, the cesium concentration in groundwater at the Test Area North at the Idaho National Engineering Laboratory is on the order of $50 \mathrm{ppb}\left(3.6 \times 10^{-7} \mathrm{M}\right)$ (PNNL 1996). The K East Basin at Hanford contains about $4.3 \mu \mathrm{Ci} / \mathrm{L}\left(3.6 \times 10^{-10} M\right)$ of ${ }^{137} \mathrm{Cs}$ resulting from corrosion of the fuel and its containers. A method of removing cesium is needed that avoids transuranic loading of the ion exchange material and does not generate large quantities of secondary waste.

Currently, the most accepted option for cesium separation before final disposal is conventional ion exchange (IX) (Kurath et al. 1994). Both inorganic and organic ion exchangers are under consideration. Unfortunately, in the current state of IX technology, a large amount of secondary waste is generated due to the numerous process steps required (acid elution, exchanger water rinse, and sodium loading of the exchanger). Neutralization of the acidic eluant typically adds sodium to the waste, restricting the choice of waste form and limiting the amount of waste that can be incorporated. In addition, it has been reported that organic exchangers lose approximately $3 \%$ of their capacity per cycle (Kurath et al. 1994). Therefore, typical organic exchangers can be used for only 20 to 30 cycles before they must also be disposed of as another form of secondary waste. 
Electrically Switched Ion Exchange (ESIX) is an approach for radioactive cesium separation that combines IX and electrochemistry to provide a selective and reversible separation method, which should produce little or no secondary waste. In the ESIX process (Figure 1), an electroactive IX film is electrochemically deposited onto a high-surface area electrode, and the IX characteristics (ion uptake and elution) are controlled directly by modulating the potential of the film. For cesium, the electroactive films under investigation are ferrocyanides, which are well-known ion exchangers (Barton et al. 1958; Harjula et al. 1994; Koukím et al. 1964; Lehto and Harjula 1987; Lehto et al. 1987; Loewenschuss 1982; Loos-Neskovic and Fedoroff 1984-1989b; Loos-Neskovic et al. 1976a, 1976b; Prout et al. 1965; Tusa et al. 1994) having high selectivities for cesium in concentrated sodium solutions (Barton et al. 1958; Harjula et al. 1994; Loos-Neskovic et al. 1976a, 1976b; Prout et al. 1965; Tusa et al. 1994). A similar system using Prussian Blue films on a platinum electrode for metal ion separations has been reported (Ikeshoji 1986). When a cathodic potential is applied to the film, $\mathrm{Fe}^{+3}$ is reduced to the $\mathrm{Fe}^{+2}$ state, and a cation must be intercalated into the film to maintain charge neutrality (i.e., cesium is loaded). Conversely, if an anodic potential is applied, a cation must be released from the film (i.e., cesium is unloaded). Therefore, to load the film with cesium, the film is reduced; to unload cesium, the film is oxidized.

The combination of IX and electrochemistry has been attempted previously. The most successful attempt has been the electrochemical ion exchange (EIX) technology developed by AEA Technology, United Kingdom (Bridger et al. 1991; Jones et al. 1992). In EIX, the IX properties of an exchanger/electrode are controlled by generating acid and base locally by water electrolysis. ESIX is significantly different because the uptake and elution of ionic species in a modified electrode or IX film are controlled by modulating the potential of the film directly without changing the local interfacial $\mathrm{pH}$.
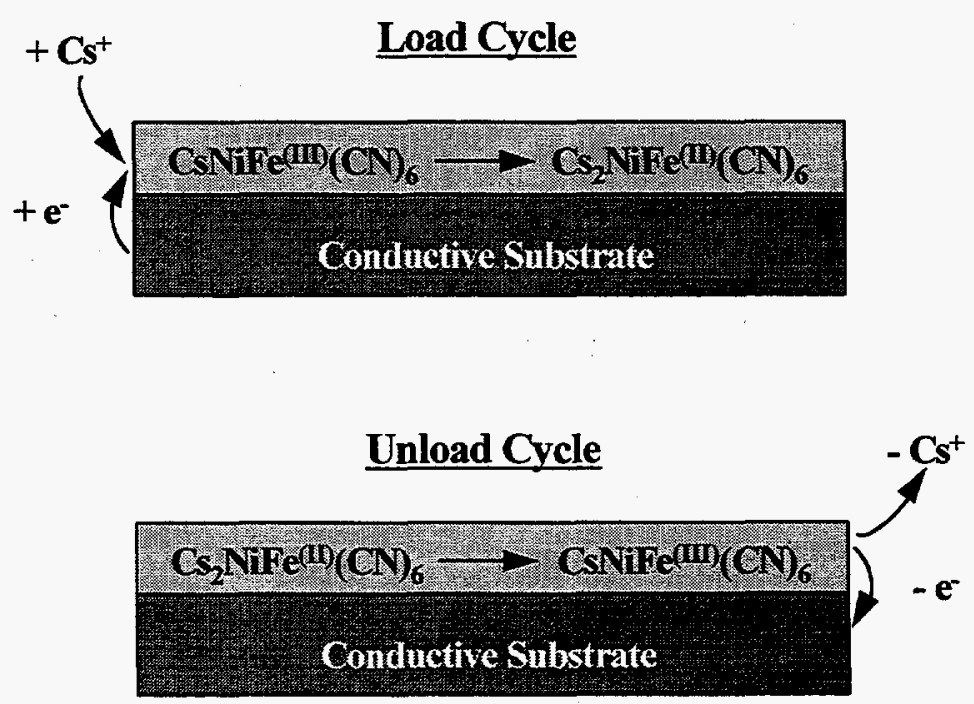

Figure 1. The ESIX concept for metal ion loading and loading 
Furthermore, the potentials used in this method do not result in the electrolysis of water, leading to more efficient use of electrical energy and eliminating the safety issues associated with hydrogen evolution.

A potential advantage of the ESIX process is that it may be possible to elute cesium into the same elution solution after several load cycles because the unload step is conducted electrochemically without added chemicals and independent of the soluble cesium concentration. This improved process would result in the generation of a waste stream with a very low sodium concentration and a cesium concentration that is limited only by solubility, radiation, and heat generation. Such a HLW feed stream could allow consideration of a broader range of final waste forms, including those that cannot tolerate sodium. This process also should not produce significant amounts of secondary waste requiring disposal as LLW, since the elution, wash, and regeneration cycles typical of standard IX are not necessary. A small amount of wash solution may be necessary, but this solution could be used in subsequent cycles for unloading the exchanger. Ratios of the volume of generated secondary waste to the volume of processed waste are estimated to be as low as 0.0006 for the ESIX process, or about two orders of magnitude lower than for a typical process using CS-100 ion exchange resin.

Modification of electrode surfaces with electroactive films has been studied extensively (Andrieux and Saveant 1980; Laviron 1980; Murray 1980, 1984). In particular, the preparation and characteristics of ferrocyanide films have been reported by several groups (Bacskai et al. 1995; Bocarsly and Sinha 1982a, 1982b; Humphrey et al. 1984, 1987; Itaya et al. 1986; Lasky and Buttry 1988; Schneemeyer et al. 1985; Sinha et al. 1984). Nickel ferrocyanide films, $\mathrm{M}_{2} \mathrm{NiFe}(\mathrm{CN})_{6}(\mathrm{M}=$ $\mathrm{Na}, \mathrm{K})$, have been prepared by dipping a nickel electrode into a $\mathrm{Fe}(\mathrm{CN})_{6}^{-3}$ solution, which oxidizes the metal electrode to precipitate the electroactive film, or more commonly by electrochemically oxidizing the nickel electrode in a $\mathrm{Fe}(\mathrm{CN})_{6}^{-3}$ solution (Bacskai et al. 1995; Sinha et al. 1984). Electrochemical deposition gave the most reproducible films with highly reversible behavior. Bocarsly and Sinha (1982b) found that the redox potential and electron transfer properties of the films demonstrated a dependance on the alkali metal cation present in the supporting electrolyte, with cesium ion greatly affecting the observed behavior. Films showed selectivity for metal cations in the order cesium $>$ potassium > sodium (Sinha et al. 1984); however, the main purpose of these studies apparently was electrocatalysis (Humphrey et al. 1987), not ion separations. Selectivity is believed to be dependant on metal ion size (Schneemeyer et al. 1985) and cation loading and unloading apparently require solvent transport (Lasky and Buttry 1988).

The overall goal of the research reported here is to develop the ESIX technology for metal ion separation. Initial work has focused on developing deposition methods that generate films with higher capacity and stability. Cyclic voltammetry and chronocoulometry are used to characterize film stability, capacity, and rates of metal ion uptake. Raman spectroscopy is being used to investigate mechanisms of film loss. Initial results of this research are reported in Section 2.2 Results and Discussion. 


\subsection{Work Accomplished}

Research completed in FY 1996 focused on the preparation of electroactive hexacyanoferrate films having improved capacity and stability. Films were prepared using modifications to the published procedures. Testing was conducted with cyclic voltammetry, chronocoulometry, and with Raman spectroscopy. Details of the experimental procedures are reported in Section 2.1 and findings are discussed in Section 2.2.

\subsection{Experimental}

A PAR 273A potentiostat/galvanostat was used to deposit and characterize films. Potentials were recorded versus a saturated calomel electrode (SCE). In basic solutions, a Zitex filter membrane made of poly(trifluoroethylene) (TFE) was used in the SCE for improved stability. Experiments were controlled and data collected with a Dell 466/MX computer via a GPIB card using LabView ${ }^{\mathrm{m}}$ software. $^{2}$

A $99.98 \%$ pure nickel substrate (Goodfellow) was used as the electrode. In one experimental setup, disks of $1.27-\mathrm{cm}$-diameter $\left(1.27 \mathrm{~cm}^{2}\right)$ were embedded in epoxy, polished, and suspended in the test solution. In another apparatus, a nickel plate was sealed to a specially built electrochemical cell with an o-ring and clamp. The exposed portion of the electrode had a diameter of $1.90 \mathrm{~cm}\left(2.84 \mathrm{~cm}^{2}\right)$. Prior to each film deposition, the substrate was abraded using a 600-grit sandpaper and thoroughly rinsed. Three different deposition procedures were used. One procedure was similar to that of Bocarsly and Sinha (1982a, 1982b), where the nickel surface was exposed to a solution of $5 \mathrm{mM}$ $\mathrm{K}_{3} \mathrm{Fe}(\mathrm{CN})_{6}$ and $0.1 \mathrm{M} \mathrm{KNO}_{3}$ and a $1.0 \mathrm{~V}$ (SCE) potential was applied to the nickel electrode for $300 \mathrm{~s}$. This method is designated the "literature" procedure. One variant of this method, entailing application of $0.65 \mathrm{~V}$ for $10 \mathrm{~min}$ followed by $1 \mathrm{~V}$ for $30 \mathrm{~min}$, was used to prepare films for chronocoulometry experiments. The other procedures were PNNL proprietary methods designated as PNNL-1 and PNNL-2. All chemicals were A.C.S. reagent grade and solutions were prepared with $18.2 \mathrm{M} \Omega-\mathrm{cm}$ water.

A nickel sponge electrode (Electrosynthesis Co., Inc.) with a nominal surface area per volume of $13 \mathrm{~cm}^{2} / \mathrm{cm}^{3}$ (20 pores per inch, ppi) was also coated with a nickel hexacyanoferrate film using the literature procedure and tested.

The characteristics of the films were determined by use of cyclic voltammetry and chronocoulometry. Cyclic voltammetry was typically conducted in $1 M \mathrm{NaNO}_{3}$ or $1 M \mathrm{CsNO}_{3}$ solutions starting from an applied potential of $0.25 \mathrm{~V}$, scanning anodically to $0.8 \mathrm{~V}$, then cathodically to $-0.1 \mathrm{~V}$, returning to $0.25 \mathrm{~V}$ (SCE) at a scan rate of $50 \mathrm{mV} / \mathrm{s}$. Chronocoulometry was conducted by stepping to $0.25 \mathrm{~V}$ (SCE) to load the film and to $0.5 \mathrm{~V}$ (SCE) to unload the film, typically in $0.5 M \mathrm{Na}_{2} \mathrm{SO}_{4}$.

Raman spectra were acquired using the $647.1 \mathrm{~nm}$ line of a krypton ion laser (Laser Ionics). The $647.1 \mathrm{~nm}$ line is a sensitive probe of the oxidation state of the film and gives minimal film degradation because it lies outside the absorption window of the material. Plasma emissions from the laser were 
removed with a narrow bandpass filter (Omega Optical). The laser was focused using an $\mathrm{f} / 10$ spherical lens. Scattered light was collected at $90^{\circ}$ from the incident beam by an $f / 1.2$ Nikon camera lens. The elastically scattered portion of the light was attenuated by an OD6 holographic notch filter (Kaiser Optical) prior to entering the spectrograph through a $100 \mu \mathrm{m}$ entrance slit. A $270 \mathrm{~cm}, \mathrm{f} / 4$ imaging spectrograph (Spex Industries model 270M) equipped with 600 and $1800 \mathrm{gr} / \mathrm{mm}$ gratings dispersed the inelastically scattered light onto a liquid nitrogen cooled two-dimensional CCD array (Princeton Instruments model LN/CCD-1024E). The spectroscopic and electrochemical instrumentation was controlled by a Macintosh Centris 650 computer running LabView v.2.2.1 over a GPIB interface. Spectra were acquired in situ from 500- $\mu$ m-diameter Ni disk and wire electrodes that were coated with a film and immersed in the sodium nitrate electrolyte. Additional details regarding the spectroelectrochemical instrumentation have been reported previously (Haight and Schwartz 1995).

\subsection{Results and Discussion}

This section presents the results of studies to make films with increased capacity and stability. Included are discussions of cesium loading and unloading and efforts to characterize the films using Raman spectroscopy. An initial engineering evaluation is also presented.

\subsubsection{Comparison of Film Preparation Methods}

Films were prepared on a nickel substrate by applying an anodic potential in a solution containing $\mathrm{K}_{3} \mathrm{Fe}(\mathrm{CN})_{6}$. The film is formed when $\mathrm{Ni}^{+2}$ ion generated at the electrode surface reacts with the ferricyanide anion to precipitate the insoluble nickel hexacyanoferrate material on the electrode surface (Eq. 1). Once the electrode has been coated, it displays the properties of the nickel hexacyanoferrate,

$$
\mathrm{Ni}^{\circ}+\mathrm{K}_{3} \mathrm{Fe}(\mathrm{CN})_{6} \rightarrow \mathrm{KNiFe}(\mathrm{CN})_{6}+2 \mathrm{~K}^{+}+2 \mathrm{e}^{-}
$$

rather than the substrate on which it was deposited. For example, Figure 2 shows a cyclic voltammogram of a bare nickel electrode in $1 \mathrm{M} \mathrm{CsNO}_{3}$ electrolyte. Within the potential range studied, only a small amount of current is passed associated with oxidation of the nickel surface. The current on the 5 th cycle is larger than that on the 15 th cycle because the electrode surface passivates as an oxide coating forms. Figure 3 shows cyclic voltammetry in $1 \mathrm{M} \mathrm{NaNO}_{3}$ electrolyte of films prepared by three different deposition protocols. The redox behavior of the surface-bound hexacyanoferrate is readily apparent.

Cyclic voltammetry shows that the ferrocyanide film may be oxidized to the ferricyanide form, which may in turn be reduced back to the ferrocyanide form. Eqs. 2 and 3, respectively, illustrate these reactions for any alkali metal counterion $\left(\mathrm{M}^{+}\right)$. Note that reduction requires uptake of a metal ion, $\mathbf{M}^{+}$, and oxidation requires release of the ion to retain charge neutrality in the film.

$$
\begin{aligned}
& \mathrm{M}_{2} \mathrm{NiFe}^{\mathrm{II}}(\mathrm{CN})_{6} \rightarrow \mathrm{MNiFe}^{\mathrm{III}}(\mathrm{CN})_{6}+\mathrm{e}^{-}+\mathrm{M}^{+} \\
& \mathrm{MNiFe}^{\mathrm{II}}(\mathrm{CN})_{6}+\mathrm{e}^{-}+\mathrm{M}^{+} \rightarrow \mathrm{M}_{2} \mathrm{NiFe}^{\mathrm{II}}(\mathrm{CN})_{6}
\end{aligned}
$$




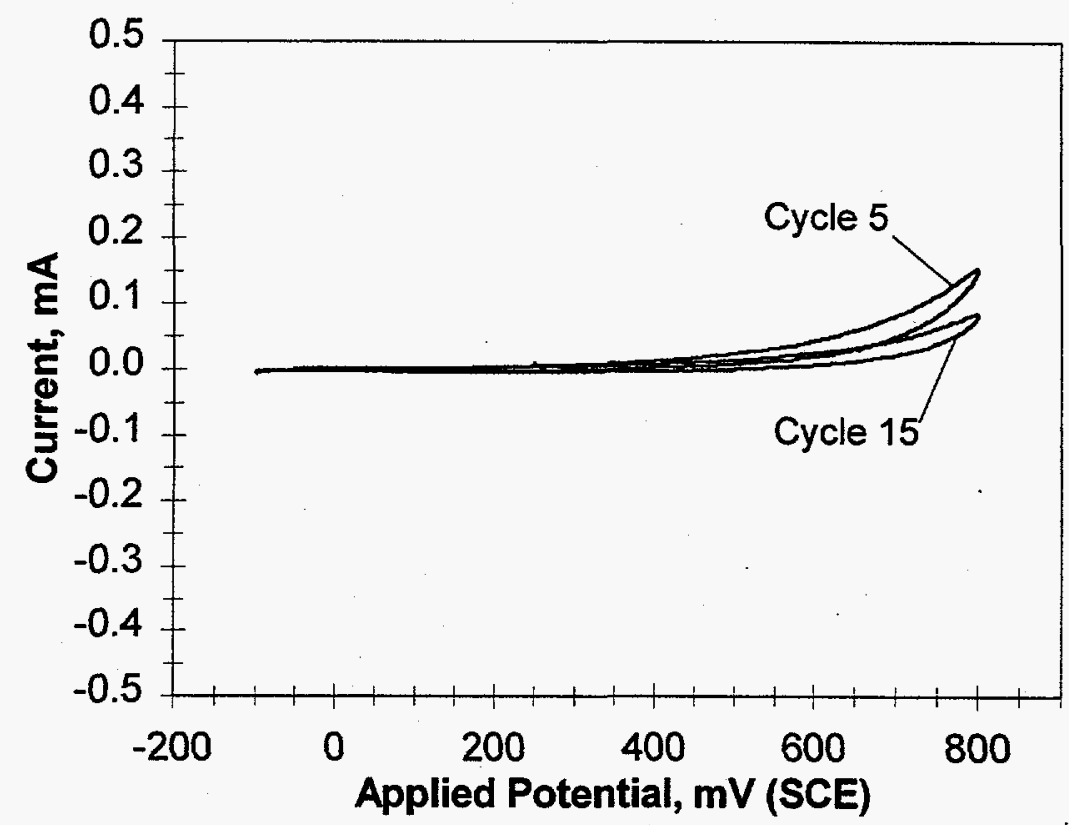

Figure 2. Cyclic voltammetry of a bare nickel electrode in $1 M \mathrm{NaNO}_{3}$

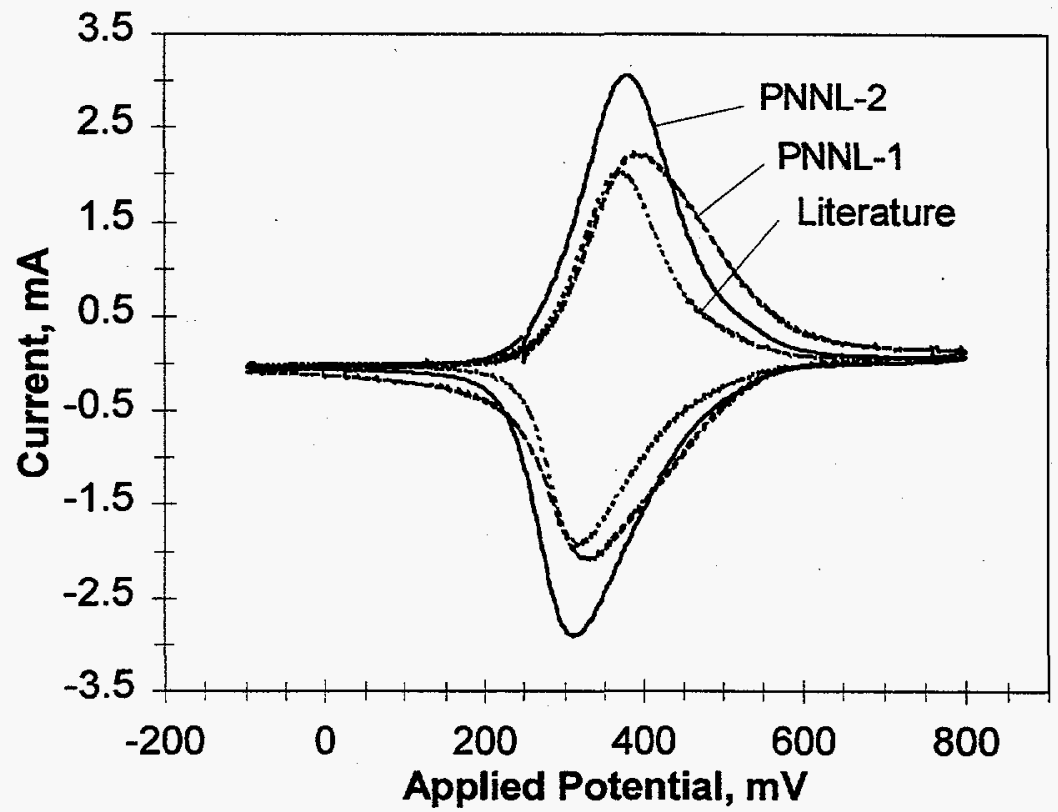

Figure 3. Cyclic voltammetry in $1 \mathrm{MNaNO}_{3}$ of hexacyanoferrate films prepared by three different methods (Cycle \#2) 
Cyclic voltammograms in Figure 3 show that the processes in Eqs. 2 and 3 are chemically reversible and that metal ion loading and unloading can be controlled by modulating the electrode potential. Films in Figure 3 are initially in the reduced state (the films are loaded). During unloading of sodium from the films, the peak current in the cyclic voltammogram occurs at about $400 \mathrm{mV}$ (SCE) and the current approaches zero at $800 \mathrm{Mv}$ as oxidation of ferrocyanide to ferricyanide nears completion. Potential scan reversal results in sodium ion uptake as ferricyanide is reduced; the peak current occurs at about $350 \mathrm{mV}$.

Figure 3 also shows that different deposition protocols give films with different capacities, as estimated by the charge passed, i.e., the area under the curve for each potential scan. The capacity of each preparation is illustrated more clearly in Figure 4, which is an integration of current passed over the course of an entire cyclic voltammetric sweep. The PNNL-prepared films using modified deposition procedures have greater capacity than the films prepared using the standard literature procedure. The maximum capacity of literature, PNNL-1, and PNNL-2 films is $2.1 \times 10^{-3} \mathrm{C} / \mathrm{cm}^{2}$, $2.6 \times 10^{-3} \mathrm{C} \mathrm{cm}^{2}$, and $3.5 \times 10^{-3} \mathrm{C} / \mathrm{cm}^{2}$, respectively. These capacities correspond to surface coverages of $2.2 \times 10^{-8} \mathrm{moles} / \mathrm{cm}^{2}, 2.7 \times 10^{-8} \mathrm{moles} / \mathrm{cm}^{2}$, and $3.6 \times 10^{-8} \mathrm{moles} / \mathrm{cm}^{2}$, respectively, for the literature, PNNL-1, and PNNL-2 films. The thickness of PNNL-2 is approximately $540 \AA$, or about 54 unit cells deep (Loos-Neskovic et al. 1984), assuming that all sites are electrochemically active (Bocarsly and Sinha 1982a; Sinha et al. 1984) and that the film is uniform.

Stable films were also deposited on $20 \mathrm{ppi}\left(13 \mathrm{~cm}^{2} / \mathrm{cm}^{3}\right)$ high surface area nickel electrodes using the literature procedure. In characterization tests using $1 M$ sodium nitrate as the test solution, films on these electrodes had surface coverages of $2.2 \times 10^{-8} \mathrm{moles} / \mathrm{cm}^{2}$, which was the same as that obtained using the 1.9-cm-diameter flat plates. These results indicate that the two electrode geometries have similar film deposition properties.

Some loss of activity occurs on repeated cycling (Figure 5). The stability of the films can be improved, however, by modifying the deposition procedure. Figure 6 compares the maximum charge passed for several different film preparations on 1.9-cm-diameter electrodes as a function of cycle number. The normalized data showing fraction of charge passed as a function of cycle number is shown in Figure 7. PNNL-2 demonstrates a loss of about $20 \%$ of its capacity after 2000 cycles. The literature film, in contrast, lost $50 \%$ of its capacity after 2000 cycles. Films on the 20 ppi high surface area nickel electrodes, prepared by the literature procedure, had stabilities more like the PNNL-2 films, losing less than $10 \%$ of their capacity after 400 cycles.

\subsubsection{Cesium Uptake/Elution}

The high affinity of hexacyanoferrates in the film for cesium is demonstrated by cyclic voltammetry. Conversion of the cesium form to the sodium form requires repeated cycling in $1 M$ $\mathrm{NaNO}_{3}$. Figure 8 shows this transformation. After two potential cycles in the unstirred solution, only about half of the film is in the sodium form. The peak for the sodium form increases upon cycling, but the affinity of the film for cesium is large enough that even after 25 cycles in initially pure $1 M \mathrm{NaNO}_{3}$, a peak associated with cesium uptake is still observed. The only cesium in this experiment is that 


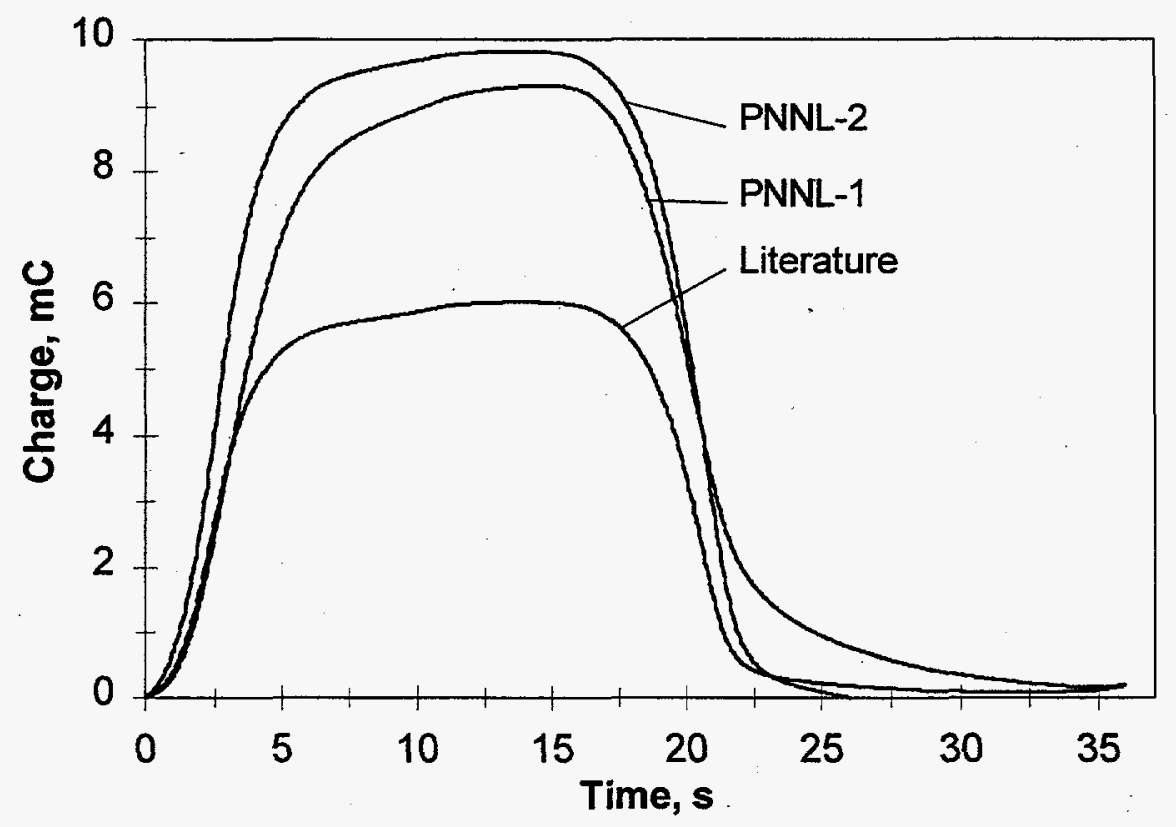

Figure 4. Charge passed as determined by integration of a single potential cycle (Cycle \#2) for three film preparations

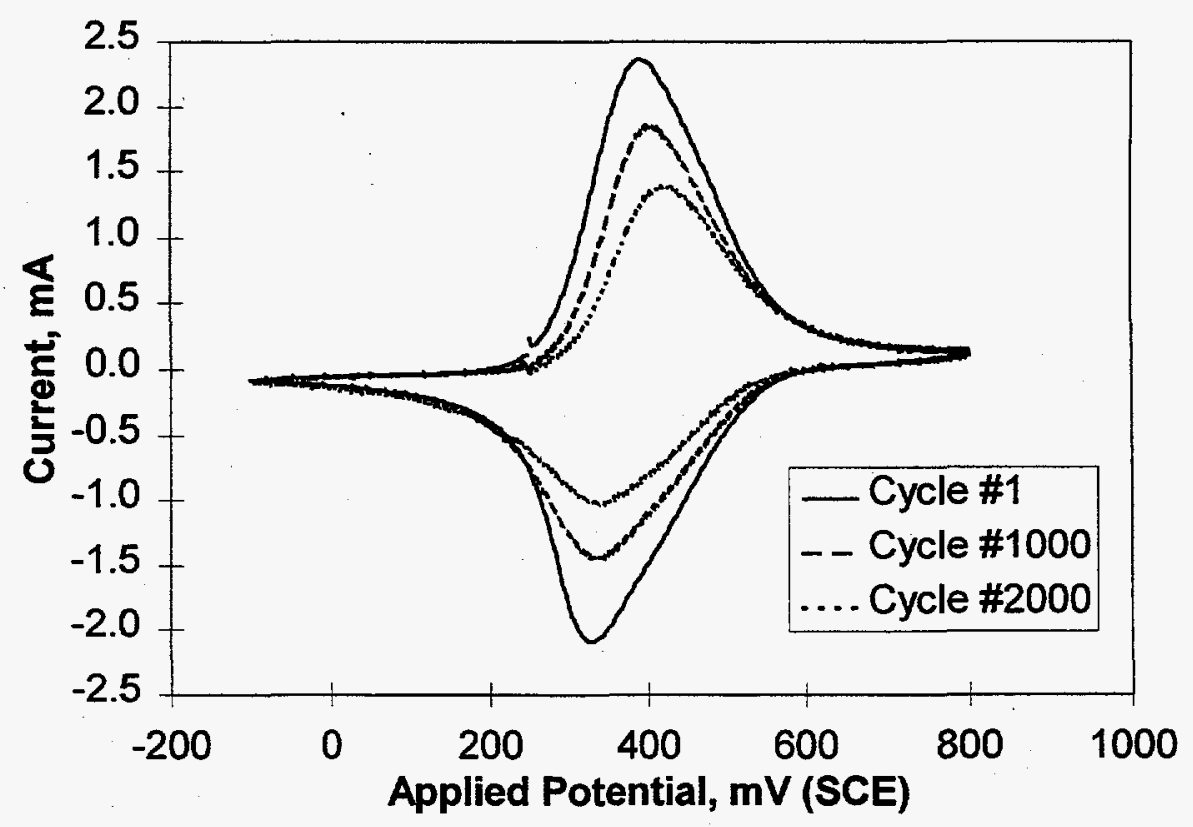

Figure 5. Repeated potential cycling of PNNL-1 in $1 \mathrm{MNaNO}_{3}$ 

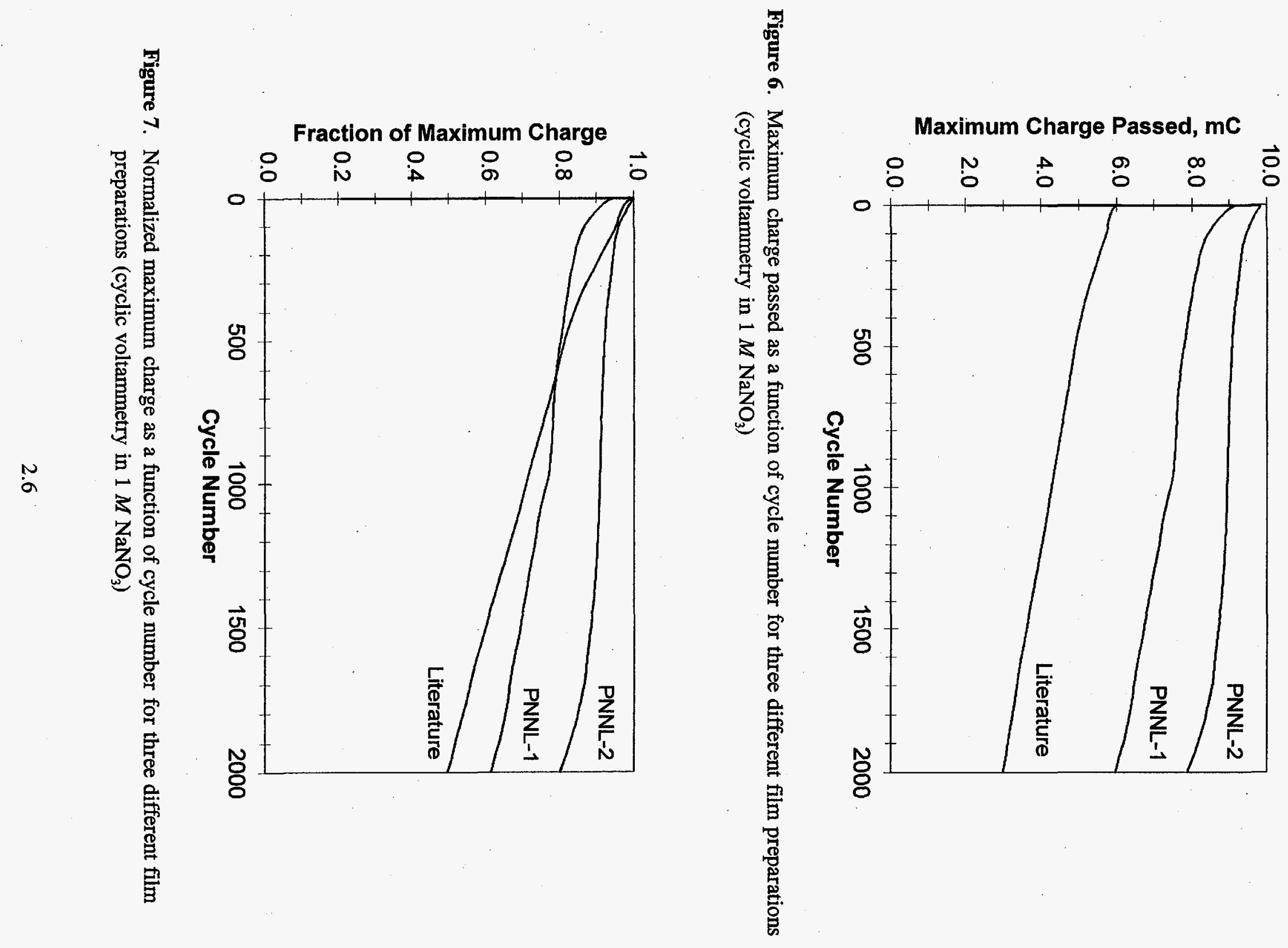


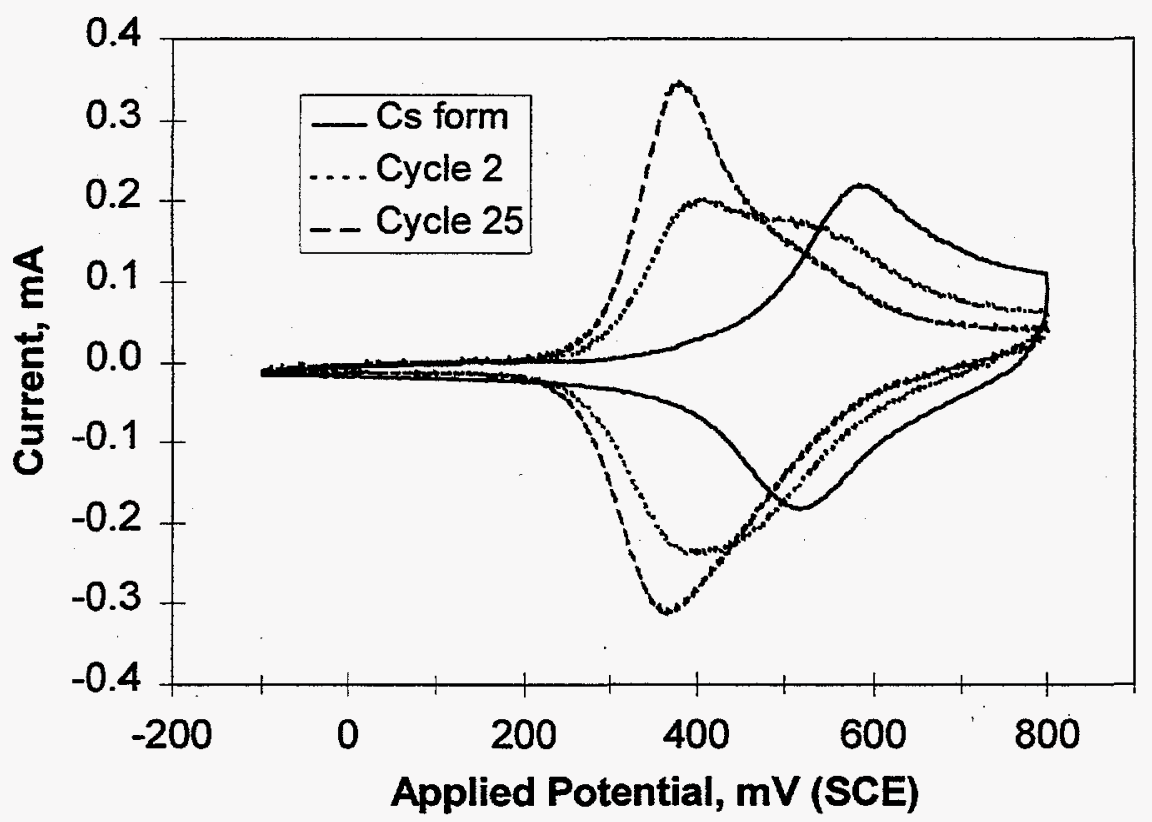

Figure 8. Cyclic voltammetry for a film in the cesium form and after two and 25 potential cycles in $1 \mathrm{M} \mathrm{NaNO}_{3}$

initially in the film, estimated to be about $1.6 \times 10^{-8}$ moles for a 1.27 -cm-diameter electrode with a surface coverage of $6.5 \times 10^{-9} \mathrm{moles} / \mathrm{cm}^{2}$. These results show that low cesium concentrations compete with high sodium concentrations for ion exchange sites in the film.

A film initially in the sodium form converts readily to the cesium form before the second potential cycle in $1 \mathrm{M} \mathrm{CsNO}_{3}$ (Figure 9). Displacement of sodium by cesium occurs during electrochemical cycling as well as by chemical ion exchange, as in a conventional ion exchange column. In other testing, it has been shown that as little as $5 \mathrm{mM}$ cesium added to a $1 M \mathrm{NaNO}_{3}$ solution converts much of the sodium form to the cesium form. Similar results were obtained by chemical analyses of films purposely dissolved. For example, films on a 1.27 -cm-diameter electrode were exposed to $5 \mathrm{mM}$ $\mathrm{CsNO}_{3}$ in $1 \mathrm{M} \mathrm{KNO}_{3}$. Dissolution of the films and analysis by atomic absorption showed significant selectivity for cesium over potassium, but the small amount of material on the electrode precluded accurate quantification. Similar testing is currently being conducted using high surface area electrodes to obtain more quantitative values.

Figures 8 and 9 show that, like sodium ion, cesium ion uptake and release is also chemically reversible. However, cesium peaks are much broader and shifted anodically. The practical consequence is that in a process for cesium separation, loading of the film with cesium requires an applied potential of about $0.55 \mathrm{~V}$ or less and unloading must be conducted at $0.60 \mathrm{~V}$ ar greater. Because sodium loading occurs at about $0.40 \mathrm{~V}$, it is possible that selectivity for cesium over sodium 


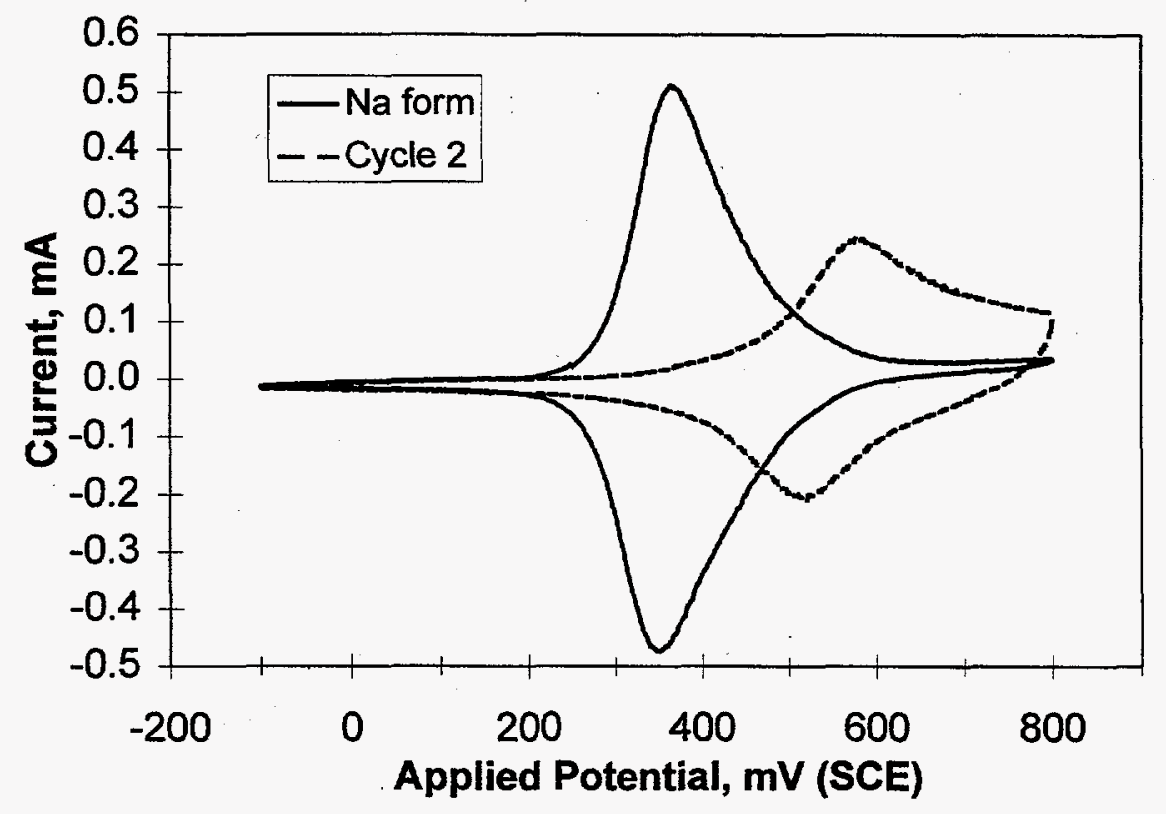

Figure 9. Cyclic voltammetry of a film in the sodium form and after two potential cycles in $1 M$ $\mathrm{CsNO}_{3}$

could be enhanced by applying the appropriate potential. The applied potential is an additional driving force to increase the $\mathrm{Cs} / \mathrm{Na}$ separation factor.

The broad anodic peak with a smaller peak current for cesium compared to sodium suggests that unloading of cesium is slower than sodium unloading. The cation dependence of the cyclic voltammetry, which has been seen before (Bocarsly and Sinha 1982b; Humphrey et al. 1984), suggests that ion diffusion through the film is the rate limiting process, consistent with the known high affinity of metal hexacyanoferrates for cesium. This high affinity forms the basis for the use of these materials as ion exchangers for the removal of cesium from nuclear waste (Barton et al. 1958; Harjula et al. 1994; Lehto and Harjula 1987; Loewenschuss 1982; Loos-Neskovic and Fedoroff 1989b; Tusa et al. 1994). The high current after the anodic cesium peak in Figures 8 and 9 indicates that cesium was still being unloaded from the film when the potential was reversed. On the time scale of the experiment, the cesium film utilized about $73 \%$ of the capacity displayed by the sodium film.

In contrast, potential step data, which are not complicated by a potential scan, indicate that the films have about the same capacity for cesium as they do for sodium. The charge that flows during electrochemical loading of sodium ion into a film in the sodium form, and of cesium ion into the same film in the cesium form, at an applied potential of $0.25 \mathrm{~V}$ is shown in Figure 10. Charge flows until the film is completely loaded. Both sodium and cesium loaded into the film to nearly the same extent. The potential step experiments more closely approximate how a process based on ESIX would operate. 


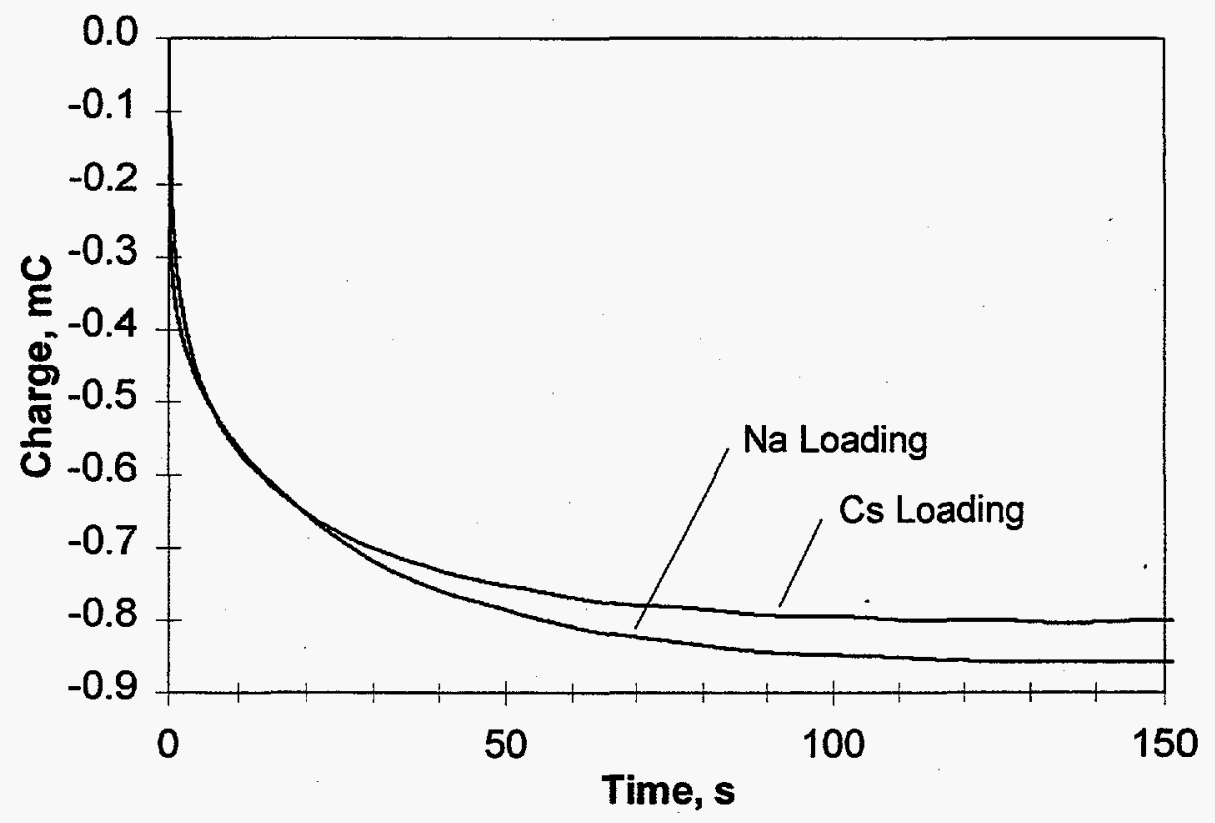

Figure 10. Loading of a film in the sodium form in $1 M \mathrm{NaNO}_{3}$ and the same film in the cesium form in $1 \mathrm{M} \mathrm{CsNO}_{3}$. Potential step to $0.25 \mathrm{~V}$.

Use of nickel hexacyanoferrate films for cesium removal from tank wastes requires stability in highly basic media. Metal hexacyanoferrates are well known to dissolve in strongly basic solutions (Bocarsly and Sinha 1982a; Lilga et al. 1996) to form nickel hydroxide and soluble hexacyanoferrate. However, nickel hexacyanoferrates containing cesium, such as $\mathrm{Cs}_{2} \mathrm{NiFe}(\mathrm{CN})_{6}$, are insoluble in up to $4 M \mathrm{NaOH}$ solutions (Lilga et al. 1996). In recent testing, electroactive nickel hexacyanoferrate films containing cesium ion are stable for over two months in $1 M \mathrm{NaOH}$ solutions containing $5 \mathrm{~m} M$ cesium ion. Application of a cathodic potential in the caustic solution results in ion uptake without significant film loss. However, without cesium in solution, the films degrade within two weeks. Apparently, the small amount of cesium in the solution sufficiently shifts the equilibrium to the insoluble cesium phases and away from the more soluble sodium phases. These results suggest that ESIX using nickel hexacyanoferrate films for cesium removal from highly basic tank wastes would most likely have to be combined with processes that reduce the $\mathrm{pH}$ of the solution (e.g., a salt-splitting process).

\subsubsection{Estimation of Rates of Ion Loading and Unloading}

Rates of sodium ion loading and unloading can be estimated from the normalized data of Figure 4. In Figure 11, fractional charge passed for each film is plotted as a function of time. The data show that for the literature film, $7.8 \mathrm{~s}$ were required to unload $95 \%$ of the film and $9.7 \mathrm{~s}$ were required to load $95 \%$ of the film. For PNNL-1, the unload and load times were $9.3 \mathrm{~s}$ and $13.9 \mathrm{~s}$, respectively; for PNNL-2, these times were $6.5 \mathrm{~s}$ and $8.9 \mathrm{~s}$. Therefore, while PNNL-1 had a higher capacity than the literature film, the rate of unloading was slower. The PNNL-2 film had superior capacity and similar rates of unloading and loading as the literature film. 


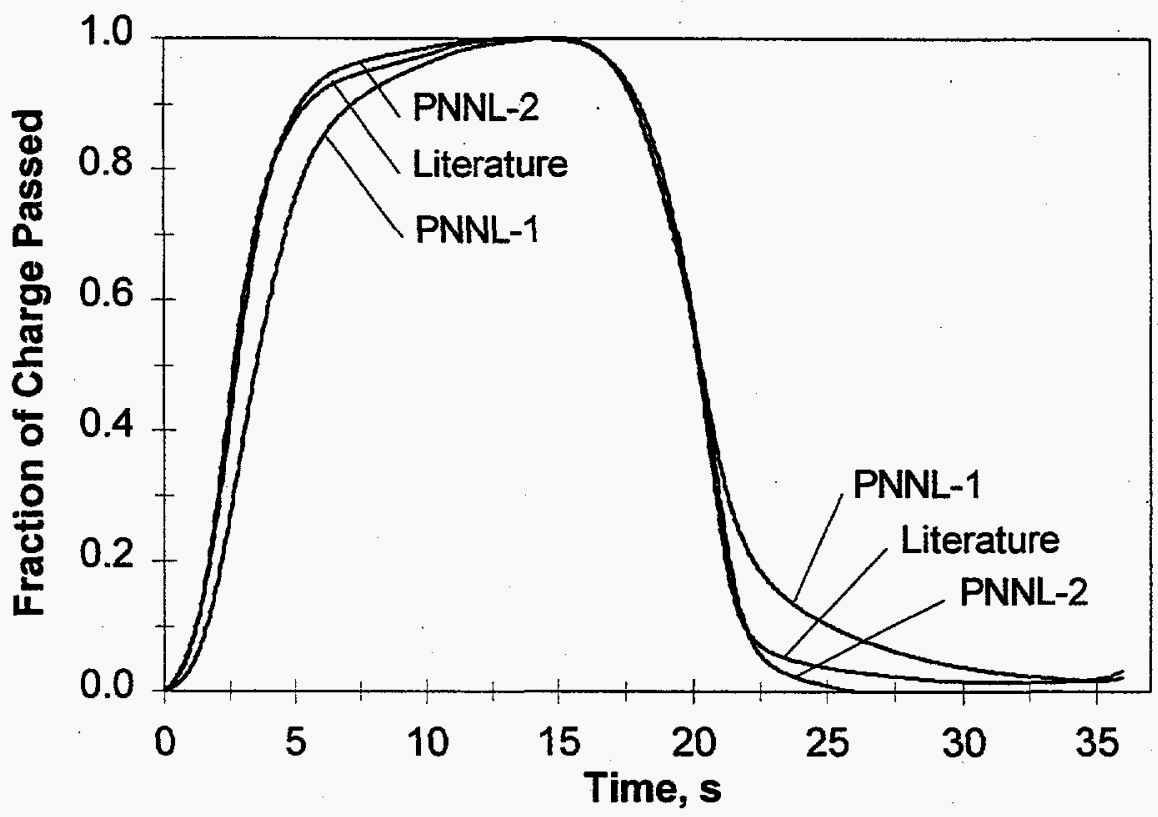

Figure 11. Normalized charge as a function of time for three different film preparations (from cyclic voltammetry in $1 \mathrm{M} \mathrm{NaNO}_{3}$ )

Another reported method (Humphrey et al. 1984; Murray 1984) to estimate the rate of diffusion through the film is to use chronocoulometry and the integrated Cottrell equation (Eq. 4) to determine

$$
C=2 \mathrm{n} F A D_{a p p}^{1 / 2} C_{0}^{*} \pi^{-1 / 2} \cdot t^{1 / 2}
$$

an apparent diffusion coefficient, $D_{\text {app }}(C=$ charge in Coulombs; $\mathrm{n}=$ equivalents of charge passed; $F=$ Faraday constant; $A=$ surface area in $\mathrm{cm}^{2} ; C_{0}{ }^{*}=$ concentration of electroactive film in moles $/ \mathrm{cm}^{3}$ ). The charge passed in a chronocoulometry experiment in which a film was loaded with sodium ion at $0.25 \mathrm{~V}$ then unloaded at $0.50 \mathrm{~V}$ is plotted as a function of time in Figure 12. This experiment was conducted in $0.5 \mathrm{M} \mathrm{Na}_{2} \mathrm{SO}_{4}$ on a $0.65-\mathrm{cm}$-diameter electrode. The film was prepared by the literature method. The total charge passed was $1.57 \mathrm{mC}$ during the load step and $1.55 \mathrm{mC}$ during the unload step, corresponding to an average surface coverage of $4.9 \times 10^{-8} \mathrm{moles} / \mathrm{cm}^{2}$.

The apparent diffusion coefficient is determined from a plot of charge as a function of the square root of time, shown in Figure 13 for the unload step. The short-time data corresponds to the condition of semi-infinite diffusion for which the Cottrell equation is valid. Using the slope of the data from 20 to $50 \%$ loading, $D_{\text {app }}$ for unloading the film is calculated to be $1.5 \times 10^{-11} \mathrm{~cm}^{2} / \mathrm{s}$. A similar analysis of cathodic chronocoulometry results gives a $D_{a p p}$ of $8.2 \times 10^{-12} \mathrm{~cm}^{2} / \mathrm{s}$ for sodium ion uptake. These diffusion coefficients are similar to those reported by the Bocarsly group (Humphrey et al. 1984). The difference in $D_{a p p}$ for loading and unloading is thought to be due to solvent exchange processes (Humphrey et al. 1984; Lasky and Buttry 1988). 


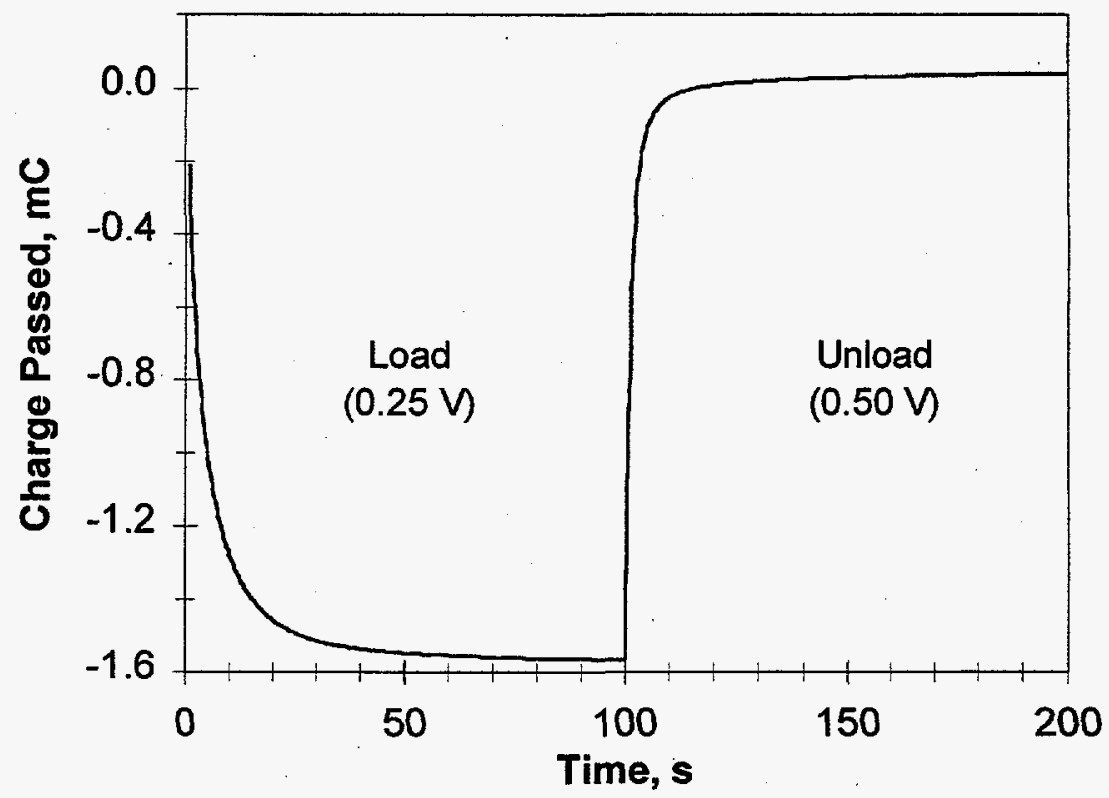

Figure 12. Potential step loading $(0.25 \mathrm{~V})$ and unloading $(0.50 \mathrm{~V})$ of a film prepared by the literature method

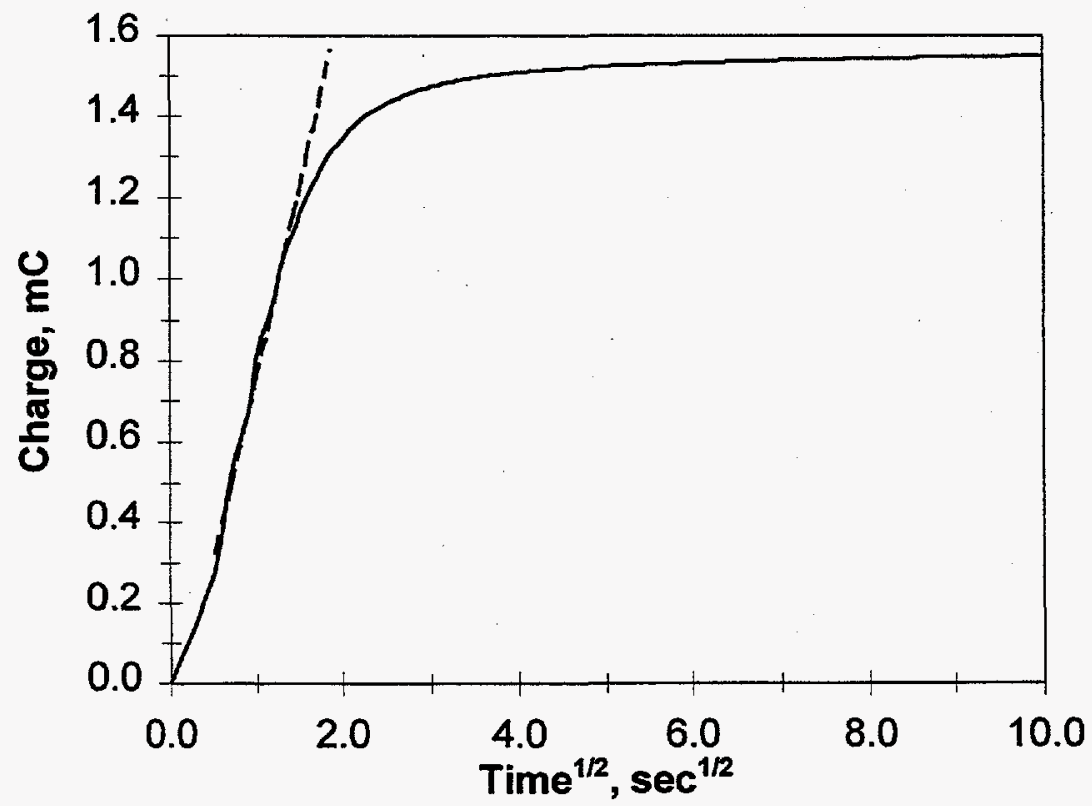

Figure 13. Cottrell plot for unloading sodium from a film prepared by the literature method 


\subsubsection{Film Characterization Using Raman Spectroscopy}

Development of a process based on ESIX technology will require use of high surface area electrodes. Associated with large electrodes are the problems of current and potential control that must be accounted for in the engineering design of the electrochemical reactor. An issue with electroactive films is whether redox reactions occur homogeneously or in islands on the electrode. Homogeneous redox reactions are desirable for predictable kinetics and process control and for efficient use of the electrode area.

The results reported here indicate that Raman spectroscopy is a sensitive probe of the oxidation state of the film. This technique is a good diagnostic tool for in situ investigations of the behavior of metal hexacyanoferrate films during redox reactions and should give information about mechanisms of film deactivation or loss. When a literature film is fully reduced with an applied potential of $-111 \mathrm{mV}$, two low wavenumber cyanide stretching modes are evident at $2103 \mathrm{~cm}^{-1}$ and $2151 \mathrm{~cm}^{-1}$, corresponding to the ferrocyanide oxidation state (Figure 14). As the applied potential is made more anodic, the film is observed to become increasingly oxidized. The film is almost completely in the ferricyanide form (peak at $2186 \mathrm{~cm}^{-1}$ ) at an applied potential of $778 \mathrm{mV}$ as shown in Figure 14. Ferro- and ferricyanide have been distinguished on potential cycling of films with thicknesses as low as about $100 \AA$ (10 unit cells thick).

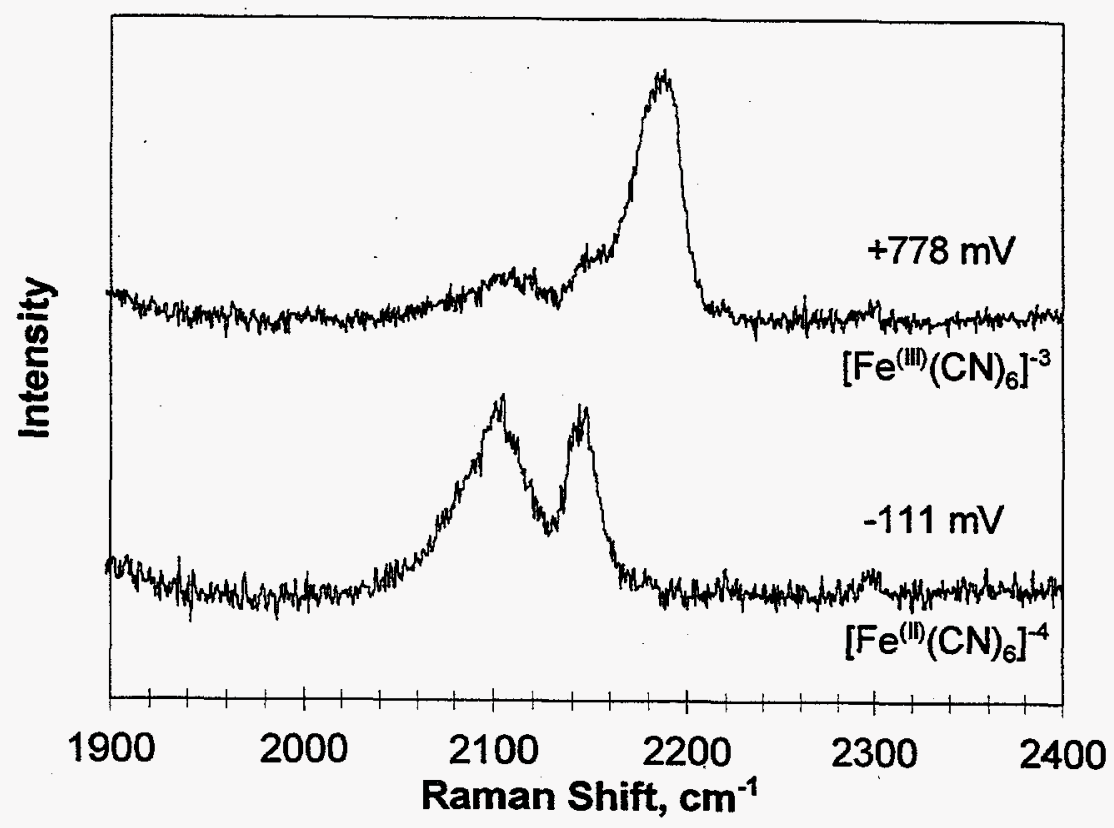

Figure 14. Raman spectra of hexacyanoferrate films on a $500-\mu \mathrm{m}$-diameter nickel disk electrode as a function of applied potential 
Imaging Raman spectroscopy shows that the thin film redox reactions occur uniformly across the film rather than in isolated regions. Raman images of a $750-\mu \mathrm{m}$-long by $30-\mu \mathrm{m}$-wide region of film were obtained as oxidation was carried out electrochemically (Figure 15). As oxidation occurred, the spatially uniform growth of ferricyanide species was observed. This is the first time that spatial uniformity of a thin film redox reaction has been demonstrated in situ. These results are important for the design of a practical ion separation system and in maintaining as uniform a current distribution as possible at a high surface area electrode.

\subsubsection{Scale-up Considerations}

In FY 1997, a bench-scale system will be designed, constructed, and tested. Thus some scale-up issues were addressed this year to prepare for the FY 1997 activities. The scale-up parameters that were considered included electrode surface area requirements, electrode materials, cell control, cell configuration (i.e., divided versus undivided), mode of operation (i.e., once-through versus batch recycle), and recommended available reactor systems. Electrosynthesis Company, Inc. was asked to assist in addressing these issues. The assumptions, calculations, and conclusions resulting from this study are given in the Appendix. The major assumptions and conclusions are summarized below.

The major assumptions used in addressing the scale-up issues are as follows:

1. The cesium concentration in the waste is $0.5 \mathrm{mM}$.

2. A uniform surface loading of $10^{-7}$ moles $/ \mathrm{cm}^{2}$ of $\mathrm{CsNiFe}(\mathrm{CN})_{6}$ should be active in the Cs insertion process.

3. The volume of effluent to be treated by the described cells is $10 \mathrm{~L} / \mathrm{h}$.

4. The process objective is to remove $99 \%$ of the Cs (decontamination factor of 100 ).

For these assumptions, required electrode surface areas were similar when based on both ion exchange capacity and mass transport considerations. (If initial cesium concentrations are lower than those assumed here, for example for Hanford $\mathrm{K}$-basin waste, the mass transport considerations become more important). This suggests that both are important to consider when designing the scaled-up system. Additionally, the required electrode surface areas were such that a three-dimensional, high surface area electrode configuration is essential.

For the given application, commercially available nickel foam and nickel felt materials are available. The nickel felt materials typically have specific surface areas at least a factor of 10 higher than the foams. However, felts have random, closed packed structures that can lead to non-uniform flow. High surface area nickel foams were recommended as the preferred electrode material. The commercially available specific electrode areas for such foams range from approximately $35 \mathrm{~cm}^{2} / \mathrm{cm}^{3}$ to $90 \mathrm{~cm}^{2} / \mathrm{cm}^{3}$. 


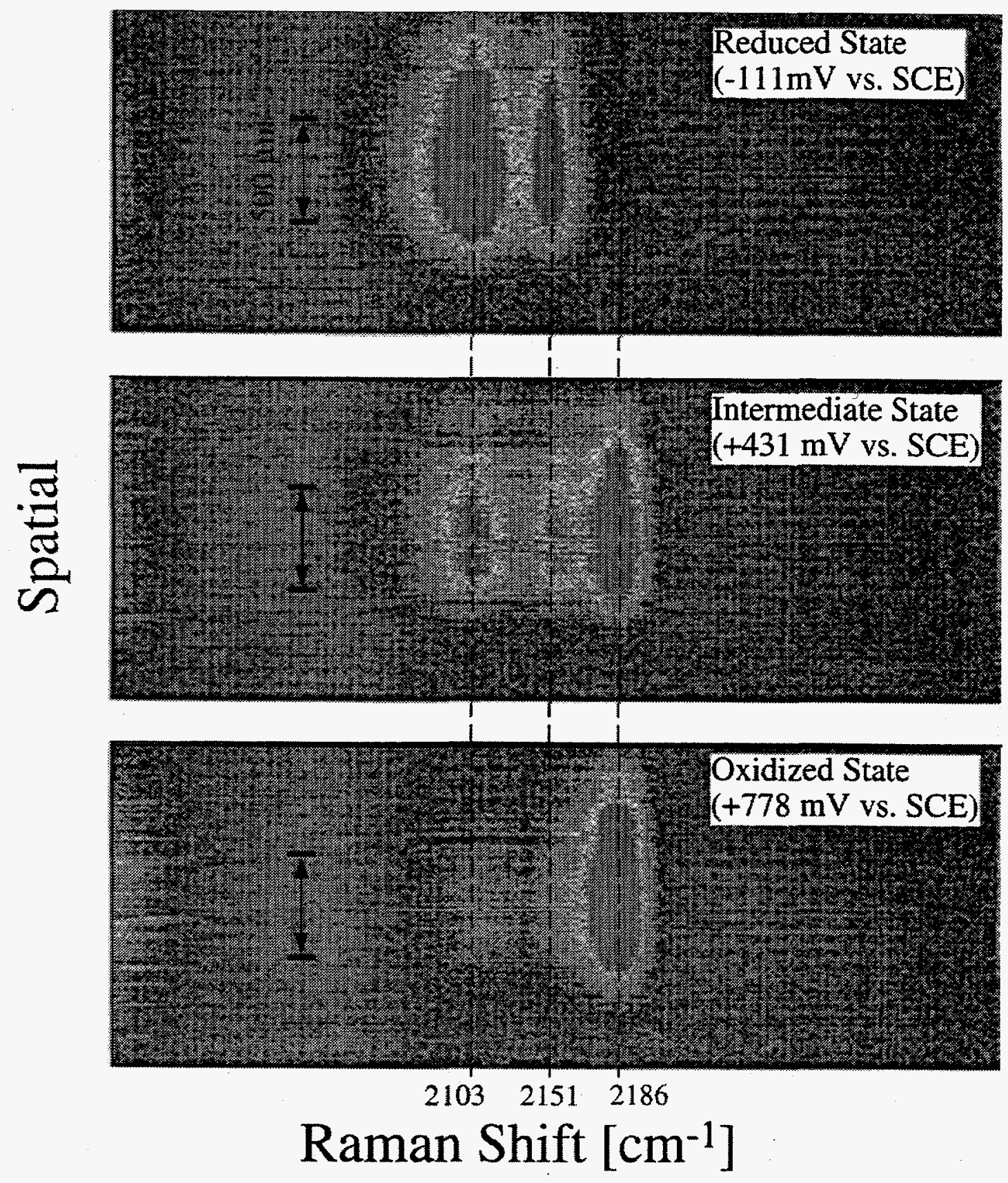

Figure 15. Imaging Raman spectra of a literature film on a nickel wire showing spatially homogeneous redox reactions 
Further investigation of controlled current operation was recommended in addition to the assumed potential control mode of operation because when a current is passed through a cell, the most readily occurring anode and cathode reactions will take place. Based on experimental evidence and ion exchange characteristics of ferrocyanide materials, when a cathodic current is passed through a nickel ferricyanide film in a solution containing $\mathrm{Na}^{+}$and $\mathrm{Cs}^{+}, \mathrm{Cs}^{+}$should preferentially be taken up by the film, and thus should be the most readily occurring reaction. To prevent excessive hydrogen or oxygen evolution when the electrode has become fully charged or discharged, it was recommended that either the electrode be oversized or a charge limit be put into the control.

Both batch recycle and once-through modes of operation were considered. Based on calculations, both modes of operation were found to be applicable and practical options. Additionally, for this application there was no advantage to using a divided cell versus an undivided cell; therefore, use of an undivided cell was recommended. Numerous commercially available reactors were recommended for this application. 


\subsection{Conclusions}

This research has demonstrated the viability of ESIX for metal ion separations. Ion loading and unloading is easily controlled by modulating the electrode potential. The use of metal hexacyanoferrates, which are known cesium ion exchange materials, is expected to give high selectivity for cesium over sodium. Films are relatively easy to prepare, but modifications to the reported procedures can generate films with significantly improved capacity and stability. The best films prepared to date have almost twice the capacity of previously reported films and lose less than $20 \%$ of their capacity after 2000 cycles. The ability to cycle through many load/unload cycles is important to the development of a practical process since the absolute capacity of a film on an electrode surface is much less than the capacity of a standard ion exchange column. Bench-scale testing is needed to determine whether cycle time and throughput are sufficient to allow ESIX to perform on a par with standard technologies, such as conventional ion exchange. If so, use of a regenerable material and the minimization of secondary waste will be significant advantages in favor of the ESIX process.

Ongoing research encompasses investigating the preparation of films with higher capacity and stability, determining the selectivity of cesium ion uptake, and designing and testing appropriate flow reactor systems for bench-scale research. The use of Raman spectroscopy to probe film loss and deactivation mechanisms is also continuing and a more-detailed discussion of these results will be published in the future. Ultimately, cesium removal from real waste streams using a flow system will be tested. 


\subsection{References}

Andrieux, C. P. and J. M. Saveant. 1980. "Electron Transfer Through Redox Polymer Films." Journal of Electroanalytical Chemistry 111:377.

Bacskai, J., K. Martinusz, E. Czirok, G. Inzelt, P. J. Kulesza, and M. A. Malik. 1995. "Polynuclear Nickel Hexacyanoferrates: Monitoring of Film Growth and Hydrated Counter-cation Flux/Storage during Redox Reactions." Journal of Electroanalytical Chemistry 385:241.

Barton, G. B., J. L. Hepworth, Jr., E. D. McClanahan, R. L. Moore, and H. H. van Tuyl. 1958. "Chemical Processing Wastes - Recovering Fission Products." Industrial and Engineering Chemistry 102:212.

Bocarsly, A. B. and S. Sinha. 1982a. "Chemically Derivatized Nickel Surfaces: Synthesis of a New Class of Stable Electrode Interfaces." Journal of the Electroanalytical Chemistry and Interfacial Electrochemistry 137:157.

Bocarsly, A. B. and S. Sinha. 1982b. "Effects of Surface Structure on Electrode Charge Transfer Properties. Induction of Ion Selectivity at the Chemically Derivatized Interface." Journal of the Electroanalytical Chemistry and Interfacial Electrochemistry 140:167.

Bridger, N. J., C. P. Jones, and M. D. Neville. 1991. "Electrochemical Ion Exchange." Journal of Chemical Technology and Biotechnology 50:469.

Gephart, R. E. and R. E. Lundgren. 1995. "Hanford Tank Clean up: A Guide to Understanding the Technical Issues. ".PNNL-10773, Pacific Northwest National Laboratory, Richland, Washington.

Haight, S. M. and D. T. Schwartz. 1995. "In situ Imaging Raman Spectroscopy of Electrochemically Deposited CuSCN." Journal of the Electrochemical Society 142:L156.

Harjula, R., J. Lehto, E. H. Tusa, and A. Paavola. 1994. "Industrial Scale Removal of Cesium with Hexacyanoferrate Exchanger - Process Development." Nuclear Technology 107:272.

Humphrey, B. D., S. Sinha, and A. B. Bocarsly. 1984. "Diffuse Reflectance Spectroelectrochemistry as a Probe of the Chemically Derivatized Electrode Interface. The Derivatized Nickel Electrode." Journal of Physical Chemistry 88:736.

Humphrey, B. D., S. Sinha, and A. B. Bocarsly. 1987. "Mechanisms of Charge Transfer at the Chemically Derivatized Interface: The $\mathrm{Ni} /\left[\mathrm{Ni}^{\mathrm{II}}(\mathrm{CN}) \mathrm{Fe}^{\mathrm{II} / 11 \mathrm{I}}(\mathrm{CN})_{5}\right]^{2-11-}$ System as an Electrocatalyst." Journal of Physical Chemistry 91:586. 
Ikeshoji, T. 1986. "Separation of Alkali Metal Ions by Intercalation into a Prussian Blue Electrode." Journal of the Electrochemical Society 133:2108.

Itaya, K, I. Uchida, and V. D. Neff. 1986. "Electrochemistry of Polynuclear Transition Metal Cyanides: Prussian Blue and Its Analogues." Accounts of Chemical Research 19:162.

Jones, C. P., M. D. Neville, and A. D. Turner. 1992. "Electrochemical Ion Exchange" in Electrochemistry for a Cleaner Environment, D. Genders and N. Weinberg, Eds., The Electrosynthesis Company Inc., East Amherst, New York, p. 207.

Koukím, V., J. Rais, and B. Million. 1964. "Exchange Properties of Complex Cyanides - I. Ion Exchange of Caesium on Ferrocyanides." Journal of Inorganic and Nuclear Chemistry 26:1111.

Kurath, D. E., L. A. Bray, K. P. Brooks, G. N. Brown, S. A. Bryan, C. D. Carlson, K. J. Carson, J. R. DesChane, R. J. Elovich, and A. Y. Kim. 1994. Experimental Data and Analysis to Support the Design of an Ion-Exchange Process for the Treatment of Hanford Tank Waste Supernatant Liquids, PNNL-10187, Pacific Northwest National Laboratory, Richland, Washington.

Lasky, S. J. and D. A. Buttry. 1988. "Mass Measurements Using Isotopically Labeled Solvents Reveal the Extent of Solvent Transport during Redox in Thin Films on Electrodes." Journal of the American Chemical Society 110:6258.

Laviron, E. 1980. "A Multilayer Model for the Study of Space Distributed Redox Modified Electrodes." Journal of Electroanalytical Chemistry 112:1.

Lehto J. and R. Harjula. 1987. "Separation of Cesium from Nuclear Waste Solutions with Hexacyanoferrate(II)s and Ammonium Phosphomolybdate." Solvent Extraction and Ion Exchange $5: 343$.

Lehto, J., R. Harjula, and J. Wallace. 1987. "Absorption of Cesium on Potassium Cobalt Hexacyanoferrate(II)" Journal of Radioanalytical and Nuclear Chemistry 111:297.

Lilga, M. A., R. T. Hallen, E. V. Alderson, M. O. Hogan, T. L. Hubler, G. L. Jones, D. J. Kowalski, M. R. Lumetta, W. F. Riemath, R. A. Romine, G. F. Schiefelbein, and M. R. Telander. 1996. Ferrocyanide Safety Project. Ferrocyanide Aging Studies Final Report, PNNL-11211, Pacific Northwest National Laboratory, Richland, Washington.

Loewenschuss, H. 1982. "Metal-Ferrocyanide Complexes for the Decontamination of Cesium from Aqueous Radioactive Waste." Radioactive Waste Management 2:327.

Loos-Neskovic, C. and M. Fedoroff. 1984. "Recovery of Silver from Solutions by Fixation on Insoluble Ferrocyanides." Annales de Chimie Science des Matériaux 9:609. 
Loos-Neskovic, C. and M. Fedoroff. 1987. "Exchange Mechanisms of Silver on Nickel and Zinc Ferrocyanides." Solvent Extraction and Ion Exchange 5:757.

Loos-Neskovic, C. and M. Fedoroff. 1988. "Exchange Mechanisms of Alkali Ions on Zinc Ferrocyanides." Reactive Polymers 7:173.

Loos-Neskovic, C. and M. Fedoroff. 1989a. "Fixation Mechanisms of Cesium on Nickel and Zinc Ferrocyanides." Solvent Extraction and Ion Exchange 7:131.

Loos-Neskovic, C. and M. Fedoroff. 1989b. "Decontamination of Liquid Nuclear Wastes by Fixation of Radioactive Elements on Nickel and Zinc Ferrocyanides." Radioactive Waste Management and the Nuclear Fuel Cycle 11:347.

Loos-Neskovic, C., M. Fedoroff, E. Garnier, and P. Gravereau. 1984. "Zinc and Nickel Ferrocyanides: Preparation, Composition, and Structure." Talanta 31:1133.

Loos-Neskovic, C., M. Fedoroff, and G. Revel. 1976a. "Use of Radioisotopes for Retention Study on Nickel Ferrocyanide." Journal of Radioanalytical Chemistry 30:533.

Loos-Neskovic, C., M. Fedoroff, and G. Revel. 1976b. "Influence of Sodium Content of Nickel Ferrocyanides on the Retention of Alkaline Ions." Radiochemistry and Radioanalytical Letters 26(1):17-26.

Murray, R. W. 1980. "Chemically Modified Electrodes." Accounts of Chemical Research 13:135.

Murray, R. W. 1984. "Chemically Modified Electrodes." in Electroanalytical Chemistry, Vol. 13, A. J. Bard, Ed., Marcel Dekker, Inc., New York.

PNNL. 1996. Efficient Separations and Processing Crosscutting Program 1996 Technical Exchange Meeting, PNNL-SA-27105, Pacific Northwest National Laboratory, Richland, Washington.

Prout, W. E., E. R. Russell, and H. J. Groh. 1965. "Ion Exchange Absorption of Cesium by Potassium Hexacyanocobalt(II)Ferrate(II). " Journal of Inorganic and Nuclear Chemistry 27:473.

Schneemeyer, L. F., S. E. Spengler, and D. W. Murphy. 1985. "Ion Selectivity in Nickel Hexacyanoferrate Films on Electrode Surfaces." Inorganic Chemistry 24:3044.

Sinha, S., B. D. Humphrey, and A. B. Bocarsly. 1984. "Reaction of Nickel Electrode Surfaces with Anionic Metal-Cyanide Complexes: Formation of Precipitated Surfaces." Inorganic Chemistry 23:203.

Tusa, E. H., A. Paavola, R. Harjula, and J. Lehto. 1994. "Industrial Scale Removal of Cesium with Hexacyanoferrate Exchanger - Process Realization and Test Run." Nuclear Technology 107:279. 


\title{
Appendix
}

\author{
Contractor Report
}

\section{Electrically Controlled Ion Exchange}

\author{
Dr. David Genders \\ Electrosynthesis Company, Inc. \\ 72 Ward Road \\ Lancaster, NY 14086
}




\section{REPORT TO BATTELLE PACIFIC NORTHWEST}

\section{PRELIMINARY PROBLEM ASSESSMENT}

\section{Assumptions}

1. The concentration of $\mathrm{Cs}^{+}$in the waste is $0.5 \mathrm{mM}$.

2. A surface loading of $\mathrm{CsNiFe}(\mathrm{CN})_{6}$ which is uniform and at least a fraction of the film equivalent to $\approx 10^{-7}$ moles $\mathrm{cm}^{-2}$ should be active in the $\mathrm{Cs}^{+}$insertion process; this is equivalent to $\approx 200$ monolayers or $\approx 0.04 \mu \mathrm{m}$.

3. The volume of effluent to be treated by the cells described is $10 \mathrm{l} /$ hour.

4. The process objective is to remove $99 \%$ of the $\mathrm{Cs}^{+}$(ie. a conversion of 0.99 ).

The electrode areas/cell sizes are likely to increase linearly with the $\mathrm{Cs}^{+}$concentration and the volume/unit time of waste to be treated. Also the electrode area required will be inversely proportional to the loading of $\mathrm{CsNiFe}(\mathrm{CN})_{6}$. In general, each order of magnitude change in the target level for removal of $\mathrm{Cs}^{+}$will change the required electrode area by a substantial factor (1.5 to 2 , see below).

\section{Preliminary comments}

\section{Surface area}

Two considerations could determine the surface area of electrode required in the cell. These are the mass transport of $\mathrm{Cs}^{+}$to the electrode surface and the ion exchange capacity of the nickel ferrocyanide film.

In electrochemical terms, the ion exchange capacity of the surface coating would normally be expressed as a charge density; a film containing $10^{-7}$ moles $\mathrm{cm}^{-2}$ has a charge density of $10 \mathrm{mC} \mathrm{cm}^{-2}$. The minimum charge (ie. assuming $100 \%$ current efficiency) required to remove $0.5 \mathrm{mM} \mathrm{Cs}^{+}$from 10 litres is $500 \mathrm{C}$. Therefore the minimum surface area needed is $5 \mathrm{x}$ $10^{4} \mathrm{~cm}^{2}$ (ie. $5 \mathrm{~m}^{2}$ ).

No electrode reaction can occur above the rate at which the reactant reaches the electrode surface. Hence, one can calculate the minimum electrode area from the viewpoint of mass transport. In fact, in a batch reactor under mass transport control the conversion is given by the equation

$$
\text { conversion }=c(t) / c(0)=\exp -k_{m} A t / V
$$


where $c(t)$ and $c(0)$ are the concentrations of reactant at time $t$ and before electrolysis respectively, $\mathrm{k}_{\mathrm{m}}$ the mass transport coefficient, $\mathrm{A}$ the electrode area, $\mathrm{V}$ the volume of waste to be treated and $t$ is the electrolysis time (all equations used in this report are taken from the book by F.C. Walsh " $A$ First Course in Electrochemical Engineering" available from the Electrosynthesis Co). In a reasonable cell design $\mathrm{k}_{\mathrm{m}}=10^{-3} \mathrm{~cm} \mathrm{~s}^{-1}$ and here $\mathrm{V}=10 \mathrm{l}=10^{4} \mathrm{~cm}^{3}$ and $\mathrm{t}=1$ hour $=3.6$ $\times 10^{3}$ s. Hence to reduce, the $\mathrm{Cs}^{+}$level to $1 \%$ of the system input ( a conversion of 0.99 ) requires

$$
\mathrm{A}=\frac{-2.3 \times(-2) \times 10^{4}}{10^{-3} \times 3.6 \times 10^{3}}=1.3 \times 10^{4} \mathrm{~cm}^{2}=1.3 \mathrm{~m}^{2}
$$

To increase the conversion to 0.999 would increase the area requirement by a factor of 1.5 while a 0.9 conversion would halve the area needed. It should be stressed that the these areas are independent of the absolute $\mathrm{Cs}^{+}$concentration (see above equation) because the current density will increase linearly with concentration (the available electrode area effectively works harder).

It can be seen that the two areas calculated from consideration of ion exchange capacity and mass transport appear not dissimilar and hence both ion exchange capacity and mass transport could be factors in cell design considerations. It is probable that the limiting factor is the nickel ferricyanide loading and we would therefore stress the importance of achieving at least the target loading.

Certainly the areas estimated from both ion exchange capacity and mass transport considerations are so large that no practical cell could employ a flat plate electrode. A three dimensional electrode will be essential.

\section{Three dimensional electrode materials}

Three dimensional electrodes have been fabricated from beds of spheres and other particles, fibers, metal wools, stacks of meshes, foams, felts etc. In this project, we are looking for materials which give both a high specific electrode area (real electrode area per unit volume) and good mass transport. Also, since it is necessary to coat the surface with nickel ferrocyanide, it is essential to select materials which can be uniformly and adequately coated. Because of cost, it is not reasonable to use precious metals and our proposals are limited to nickel and either carbon or base metal supports.

Foams are attractive materials which have been successfully employed as electrodes by several groups. They have a uniform structure and a high porosity; hence it should be possible to coat them. Moreover, they have a low electrical resistance and give satisfactory mass transport coefficients. Nickel foams are available and have been used as electrodes (eg, Langlois et al., $J$. Applied Electrochem., 19 (1989) 43, 51 and 736, Tissot el al 26 (1996) 211). Reticulated vitreous carbon electrodes are perhaps more common electrode materials (eg, Pletcher et al, J. Applied Electrochem., 21 (1991) 659 and 667 and 23 (1993) 82). Some properties relevant to this project are summarized in table 1 and it can be seen that the properties of $\mathrm{Ni}$ foam and reticulated vitreous carbon are similar. For example it can be seen that the real area of $5 \times 10^{4}$ 
$\mathrm{cm}^{2}$ for the treatment of 10 litres could be achieved with $\approx 500-1000 \mathrm{~cm}^{3}$ of 100 ppi material. A typical thickness of foam in electrolytic applications is $1.2 \mathrm{~cm}$ and hence a piece of foam 400 $800 \mathrm{~cm}^{2}$ would suffice. The $\mathrm{Ni}$ foams are available from the Electrosynthesis Co and also from Sorapec in France. Both Ni foam and reticulated vitreous carbon have been used commercially in the Retec technology.

$\mathrm{Ni}$ and carbon felts are also available from Sorapec and the Electrosynthesis Co and these have specific surface areas at least a factor of ten higher than the foams. Certainly, values of $\mathrm{k}_{\mathrm{m}} \mathrm{A}_{\mathrm{e}}$ determined electrochemically are higher by a factor of ten for the felts than the foams and this appears to enhance cell performance substantially. Moreover Ni felt (Electrochim Acta 32 (1987) 1303) and carbon felt (Porocell technology, pilot and laboratory scale work by the Electrosynthesis Co and others) have been used in electrolytic cells. The problem with felts is that they have a random, close packed structure and it can be difficult to achieve uniform pumping rates through electrodes of any size. It is usually particularly difficult to coat such structures uniformly and we believe that it would be much more difficult to produce an acceptable coating of nickel ferrocyanide on the felts compared to the foams.

The foams and felts would be our preferred cathode materials although there are others which could be tested. For example, Olin now market a three dimensional Ti material, known as Tysar $^{\mathrm{R}}$ which it may be possible to Ni plate; they are also believed to be developing a Ni (as well as steel) based structure of this type (specific surface areas $90-500 \mathrm{~cm}^{2} \mathrm{~cm}^{3}$ ). Sintered Ni with various porosities are used in the battery industry and it is also possible to consider stacked mesh electrodes or metal wools.

Clearly, the successful coating of any material with nickel ferricyanide is a requisite to application in the electrolytic cell and the choice of cathode will depend on the coating technology which will be developed.

\section{CELL CONTROL STRATAGIES}

\section{Controlled potential vs controlled current}

The proposal EM-50 seems to assume that the potential of the nickel ferri/ ferrocyanide coated electrode will need to be controlled even in the scaled up technology. This would be very expensive and appears at first sight to be unnecessary. When a current is passed through a cell, the most readily occurring anode and cathode reaction take place. On the basis of the voltammetry reported, there is little doubt that when a cathodic current is passed through a nickel ferricyanide coating in a solution of $\mathrm{Na}^{+} / \mathrm{Cs}^{+}$, it is the $\mathrm{Cs}^{+}$which will go into the film. Moreover, the reaction has another desirable feature; in a three dimensional electrode, the uniformity of the reaction can be problem. This will not be the case here because once the film in one area of the electrode is filled with $\mathrm{Cs}^{+}$, the local current will drop to zero and the $\mathrm{Cs}^{+}$will insertion in the next available zone; the insertion reaction zone will move through the thickness of the electrode. Hence, it would be possible to operate with relative thick foam electrodes, where in other situations, much of the thickness would be inactive due to IR drop. We recommend strongly that controlled current operation be investigated. 
The preferred constant current can be determined experimentally, for example, by voltammetry. The only likely hazard is hydrogen/oxygen evolution if electrolysis is allowed to continued when the electrode has become fully charged/discharged with $\mathrm{Cs}^{+}$. Then, either the extreme of potential or the gas evolution could damage/disrupt the nickel ferri/ ferrocyanide film. This could be avoided by oversizing the electrode or putting a charge limit into the control regime.

\section{Divided vs undivided cell}

There is no compelling reason to include a membrane or porous separator in the cell . design. During removal of the $\mathrm{Cs}^{+}$from solution the counter electrode reaction will probably be oxygen evolution and during discharge of the nickel ferrocyanide film it will be hydrogen evolution. Neither will interfere with the working electrode chemistry and $\mathrm{Cs}^{+}$will itself not oxidize/reduce. Other trace components of the waste stream may be electroactive but this may not be regarded as a disadvantage. Moreover, the charge put into the waste stream is small because of the low $\mathrm{Cs}^{+}$. Since undivided cells are cheaper and more flexible, we recommend the use of undivided cells.

The current from $1 \mathrm{~cm}^{3}$ of foam may be estimated from the equation

$$
\mathrm{I}=\mathrm{nFk}_{\mathrm{m}} \mathrm{A}_{\mathrm{e}} \mathrm{V}_{\mathrm{e}} \mathrm{c}
$$

For a $0.5 \mathrm{mM}\left(5 \times 10^{-7} \mathrm{~mol} \mathrm{~cm}^{-3}\right)$ solution of $\mathrm{Cs}^{+}$and 100 ppi foam (for data see table 1), this current is $\approx 10 \mathrm{~mA}$. Hence, in the designs outlined below, the current density on the counter electrode will be $10-50 \mathrm{~mA} \mathrm{~cm}$. This is a quite normal value in effluent treatment cells. In all cell configurations, an appropriate counter electrode material will need to be selected. It will act alternately as anode and cathode during load/release of $\mathrm{Cs}^{+}$and this prevent the use of some materials. The choice might depend on the $\mathrm{pH}$ and composition of the waste.

\section{Solution - once through cell or batch recycle operation}

The cell may be operated either in the once through mode where the required depletion is achieved in a single pass or by recycling a batch through the cell.

\section{Once through operation}

The solution flow is fixed at 10 liters/hour or $3.6 \mathrm{~cm}^{3} \mathrm{~s}^{-1}$. For a reasonable mean linear flow rate, say $1 \mathrm{~cm} \mathrm{~s}^{-1}$, this fixes the area of the electrolyte chamber, $A_{x}$, at $3.6 \mathrm{~cm}^{2}$ or $3 \mathrm{~cm} \mathrm{x} 1.2$ $\mathrm{cm}$ using standard materials. Assuming mass transport control, the electrode length, $\mathrm{L}$, required for $99 \%$ removal is given by

$$
L=\frac{2.3 Q_{\mathrm{V}}}{A_{\mathrm{x}} \mathrm{k}_{\mathrm{m}} \mathrm{A}_{\mathrm{e}}} \log \mathrm{c}_{\text {out }} / \mathrm{c}_{\text {in }}
$$


where $\mathrm{Q}_{\mathrm{v}}$ is the volumetric flow rate. Substituting values (see assumptions and table 1) into the equation, gives an electrode length of $\approx 50 \mathrm{~cm}$. for a conversion of 0.99 for a mass transport controlled reaction. In fact, this gives an electrode volume of only $180 \mathrm{~cm}^{3}$. This is insufficient to provide the area of nickel ferricyanide to accept all the $\mathrm{Cs}^{+}$in solution. The calculation above suggested a requirement of $500-1000 \mathrm{~cm}^{3}$ from this point of view. Changing the electrode thickness or width to increase the electrode volume will decrease the mean linear flow rate and hence decrease the mass transport coefficient. Even so an electrode $1.2 \mathrm{~cm}$ thick $\mathrm{x} 10 \mathrm{~cm}$ wide $\mathrm{x}$ $100 \mathrm{~cm}$ long should lead to a $99 \%$ removal with some safety margin. This is an unusual shape for a commercial cell but could readily be constructed.

\section{Batch recycle operation}

In this mode of operation, the 10 liters of effluent would be placed in a reservoir and this solution would be recycled continuously through the cell. This is a convenient way to carry out most experiments in the laboratory since it removes the relationship between electrode dimensions and flow rate. The solution may therefore be circulated rapidly giving a much enhanced mass transport coefficient. It also "fits" commercial cell designs. The disadvantage is that unless the intention is to carry out batchwise the waste treatment process, it is a poor model for scale up.

It is likely that a mass transport coefficient of $5 \times 10^{-3} \mathrm{~cm} \mathrm{~s}^{-1}$ can be achieved in, for example, an MP or ElectroSyn cell with a foam cathode. Equation (1) would apply to this experiment giving an area requirement for a mass transport controlled reaction would be only 2.5 $x 10^{3} \mathrm{~cm}^{2}$ or a piece of foam with a volume $\approx 30 \mathrm{~cm}^{3}$. Here, therefore, the factor determining the electrode area would clearly be the surface loading of nickel ferricyanide; the area estimated above was $5 \times 10^{4} \mathrm{~cm}^{2}$ equivalent to a foam volume of $\approx 600 \mathrm{~cm}^{3}$. Allowing some safety margin would suggest $\approx 1000 \mathrm{~cm}^{3}$.

Because of the dominance of the ion exchange capacity in determining electrode size, there appears to be unusually little disadvantage in operating in the once through mode. We therefore recommend the use of once through designs although in preliminary flow cell experiments there is some attraction in employing a smaller volume of waste (say 1 liter) and a small commercial cells in the batch recycle mode.

\section{RECOMMENDED REACTOR DESIGNS}

For each of the recommended commercial reactors, advertising literature is attached. Only specific comments are attached. Throughout the suggested electrode material is nickel foam although the alternatives described above should also be tested in at least one cell provided they can be satisfactorily coated with nickel ferricyanide.

\section{Electrocell $\mathbf{A B}$}

The electrode volume and length would be readily achieved with an ElectroSyn reactor with 5 undivided cells in series with their electrolyte chambers fitted with $4 \mathrm{~mm}$ thick foam and a 
polymer mesh to avoid shorting of the cell. These cells are not routinely marketed with foam electrodes but it is possible to replace the turbulence promotes with foam contacted through a back plate. Estimated cost $\$ 6,000$ for an undivided cell with projected area of $0.4 \mathrm{~m}^{2}$.

\section{Retec Cell}

This is an upgraded tank cell design which is certainly adequate at the 10 liter scale but may not be suitable for substantial scale up or remote operation. We would suggest the RETEC 6 . Cost : $\$ 7300$. It is probably necessary to use non standard counter electrodes (the DSA anodes may not be stable as cathodes).

\section{Porocell}

This is normally an undivided tubular cell with most of the cylinder volume filled with a carbon felt. A standard cell has the dimensions of $50 \mathrm{~cm}$ long $\times 18 \mathrm{~cm}$ diameter which would have the required ion exchange capacity if packed with uniformly coated carbon felt or $\mathrm{Ni}$ foam. Cost: $\$ 6,400$ for a $1 \mathrm{~m}^{2}$ cell and $\$ 4,500$ for a $0.5 \mathrm{~m}^{2}$ cell.

\section{Aquanautics Cell}

This is another parallel plate reactor which could be modified to take a $\mathrm{Ni}$ foam electrode. A standard ABC-250 cell stack with three foam working electrodes in series would give the required electrode volume and length. Cost: $\$ 3,500$ for a cell containing $250 \mathrm{~cm}^{2}$ projected electrode area.

\section{Purpose Built Cells}

We would also wish to consider the design and fabrication of purpose built cells with cylindrical or rectangular geometries. Commercial cells are generally designed for processes where mass transport is a critical consideration; with the slow flow rates which fulfill the process requirements, it should be straightforward and cheap to develop purpose built cells.

We would stress that the employment of larger cells $\left(1 \mathrm{~m}^{2}\right)$ when the program is extended to higher treatment rates will be cheaper per unit volume of waste. On the other hand, further scale up is achieved by increasing the number of cells and the cell investment cost will then be almost proportional to the number of cells. 
Ni foam

specific electrode area $/ \mathrm{cm}^{2} \mathrm{~cm}^{-3}$

$45 \mathrm{ppi}$

$60 \mathrm{ppi}$

$100 \mathrm{ppi}$

RVC

$30 \mathrm{ppi}$

$60 \mathrm{ppi}$

100 ppi

$$
\begin{aligned}
& 35 \pm 9 \\
& 58 \pm 8 \\
& 92 \pm 10
\end{aligned}
$$

$1.4 \times 10^{-3}$

$1.3 \times 10^{-3}$

$1.5 \times 10^{-3}$

Table 1 Specific surface areas, $A_{e}$, estimated from pressure drop measurements and mass transfer coefficients, $\mathrm{k}_{\mathrm{m}}$, taken from limiting current measurements. Data from J. Applied Electrochem., 19 (1989) 43, 51 and J. Applied Electrochem., 21 (1991) 659. $\dagger$ at a mean linear flow rate of $1 \mathrm{~cm} \mathrm{~s}^{-1}$ 


\section{Distribution}

No. of

\section{Copies}

\section{OFFSITE}

2 DOE/Office of Scientific and Technical Information

Dr. Moses Attrep, Jr. Los Alamos National Laboratory P.O. Box 1663, MS J514

Los Alamos, NM 87545

Ms. Debra A. Bostick

Oak Ridge National Laboratory

P.O. Box 2008

Oak Ridge, TN 37831-6201

Professor Daryle Busch

University of Kansas

Department of Chemistry

Lawrence, KS 66045

Professor Greg Choppin

Florida State University

Department of Chemistry

600 West College Avenue

Tallahassee, FL 32306

Ms. Julie E. Connor

U.S. Department of Energy

Idaho Operations Office

765 Lindsay Blvd., Mailstop 1225

Idaho Falls, ID 83401

Dr. Dirk Gombert

Lockheed Martin Idaho Technologies

P.O. Box 1625, Mail Stop 3875

Idaho Falls, ID 83415
No. of

Copies

Mr. Kurt Gerdes

U.S. Department of Energy

Program Manager

Efficient Separations and Processing

Office of Science and Technology

EM-53 CL

19901 Germantown Road

Germantown, MD 20874

Mr. Scott Haight

University of Washington

Deptment of Chemical Engineering

Box 351750

Seattle, WA 98195-1750

Dr. Jerry L. Harness

U.S. Department of Energy

Oak Ridge Operations Office

P.O. Box 2001, 3-MAIN

Oak Ridge, TN 37831

Prof. Dennis Kelsh

Gonzaga University

Department of Chemistry

E. 505 Boone Ave.

Spokane, WA 99258-0001

Prof. KNona Liddell

Washington State University

Department of Chemical Engineering

Pullman, WA 99164-2710

Mr. Phil McGinnis

Martin Marietta Energy Systems

4500-N, MS-6273

P.O. Box 2008

Oak Ridge, TN 37831

Distr.1 
No. of

\section{Copies}

Dr. Don Orth

124 Vivion Drive

Aiken, SC 29803

Dr. Martin Steindler

Argonne National Laboratory

9700 South Cass Avenue

Argonne, IL 60439

Dr. Dee Stevenson

3367 E. Bernada Drive

Salt Lake City, UT 84124

Dr. John Swanson

1318 Cottonwood Dr.

Richland, WA 99352

Dr. Ian R. Tasker

Waste Policy Institute

Quince Diamond Executive Center

555 Quince Orchard Road

Gaithersburg, MD 20878-1437

Dr. Major Thompson

Savannah River Technology Center

P.O. Box 616

Aiken, SC 29802

Dr. Jack Watson

Oak Ridge National Laboratory

P.O. Box 2008

Oak Ridge, TN 37831-6149

Dr. James Phelan

Sandia National Laboratories

P.O. Box 5800, Mail Stop 0719

Albuquerque, NM 87185-0719
No. of

\section{Copies}

Dr. J. A. Wright

U.S. Department of Energy

Savannah River Operations Office

P.O. Box A

Aiken, SC 29808

John Mathur

U.S. Department of Energy

Office of Science and Technology

EM-53 CL

19901 Germantown Road

Germantown, MD 20874

Dr. John H. Kolts

U.S. Department of Energy

Idaho Operations Office

765 Lindsay Blvd., Mailstop 1147

Idaho Falls, ID 83401

Dr. Ray Wymer

188A Outer Drive

Oak Ridge, TN 37831

Dr. Daniel T. Schwartz

University of Washington

Deptment of Chemical Engineering

Box 351750

Seattle, WA 98195-1750

Dr. J. David Genders

Electrosynthesis Company, Inc.

72 Ward Road

Lancaster, NY 14086-9779 
No. of

Copies

\section{ONSITE}

2 DOE Richland Operations Office
R. A. Pressentin K8-50
B. M. Mauss K8-50

Lockheed Martin Hanford Company

J. N. Appel G3-21

Numatec Hanford Company

R. A. Kirkbride H5-27

ITH

D. K. Oestreich H9-10

SGN Eurisys Services Corporation

R. K. Biyani L5-31
No. of

\section{Copies}

24 Pacific Northwest National Laboratory

E. G. Baker P8-38

W. F. Bonner K9-14

G. N. Brown P7-25

J. L. Buelt P7-41

R. T. Hallen P8-38

W. L. Kuhn K2-21

D. E. Kurath $\quad$ P7-20

J. P. LaFemina K9-91

M. A. Lilga (5) P8-38

R. J. Orth K3-75

M. E. Peterson K2-47

S. D. Rassat P7-41

S. C. Slate K9-14

T. L. Stewart K9-91

J. P. H. Sukamto P7-41

Technical Report Files (5) 